\title{
Optimum nitrogen rate to maintain sustainable potato production and improve nitrogen use efficiency at a regional scale in China. A meta-analysis
}

\author{
Chong Wang ${ }^{1,2} \cdot$ Huadong Zang $^{1} \cdot$ Jiangang $\mathrm{Liu}^{3} \cdot$ Xiaoyu Shi ${ }^{1,2} \cdot$ Shuo $\mathrm{Li}^{1,2} \cdot$ Fu Chen $^{1,2} \cdot$ Qingquan Chu ${ }^{1,2}$
}

Accepted: 3 September 2020 / Published online: 21 September 2020

(C) INRAE and Springer-Verlag France SAS, part of Springer Nature 2020

\begin{abstract}
The great challenges of ensuring global food security and reducing environmental risk caused by excessive fertilizer inputs require optimizing fertilizer rates to maintain crop production and environmental sustainability. Previous results regarding optimizing Nfertilizer rate for potato were mainly based on case studies and lacked regional-scale information on $\mathrm{N}$-fertilizer management. We hypothesized that regional optimum $\mathrm{N}$ rates would increase $\mathrm{N}$ use efficiency without sacrificing potato yield compared with low and high $\mathrm{N}$ rates. We determined the optimal $\mathrm{N}$-fertilization rates for Chinese potato production at a regional scale based on a dataset of 706 observations from 142 peer-reviewed publications. The linear-plus-plateau model was used to estimate regional optimum $\mathrm{N}$ rates, which were $115,150,120$, and $126 \mathrm{~kg} \mathrm{~N} \mathrm{ha}^{-1}$ for the northern, central, southwestern, and southern regions of China, respectively. The target yield could be obtained by applying less $\mathrm{N}$ fertilizer when the indigenous $\mathrm{N}$ supply was higher across the main potato production region in China. Compared with high $\mathrm{N}$ rates, recommended $\mathrm{N}$ rates increased $\mathrm{N}$ use efficiency and agronomic efficiency by $48.60-81.67 \%$ and $17.12-72.90 \%$, respectively, without any yield losses. Recommended $\mathrm{N}$ rates also achieved 5.95-14.70\% greater yield than low $\mathrm{N}$ rates. Here, we show for the first time that, based on a comprehensive literature review, regional optimum $\mathrm{N}$-fertilizer rates result in increased yield and $\mathrm{N}$ use efficiency, and reduced negative environmental impacts, all of which play a vital role in maintaining sustainable potato production. The present study highlights the importance of research for achieving a reasonable trade-off between food security and $\mathrm{N}$-fertilizer management for sustainable agriculture.
\end{abstract}

Keywords Recommended nitrogen rate $\cdot$ Nitrogen use efficiency $\cdot$ Yield $\cdot$ Indigenous nitrogen supply $\cdot$ Environmental sustainability

\section{Introduction}

The world population is projected to reach 9 billion by the mid-twenty-first century (Godfray et al. 2010). Meeting the future food demand derived from the expansion in the population will require increasing yields without aggravating environmental risks or increasing cropland expansion. Potato (Solanum tuberosum L.) production may play an important

Qingquan Chu

cauchu@cau.edu.cn

1 College of Agronomy and Biotechnology, China Agricultural University, Beijing 100193, China

2 Key Laboratory of Farming System, Ministry of Agriculture and Rural Affairs, Beijing 100193, China

3 The Institute of Vegetables and Flowers Chinese Academy of Agricultural Sciences, Beijing 100081, China role in this context since it is the fourth most important food crop in the world after rice, wheat, and maize. China is the largest producer of potato, accounting for around $20 \%$ of global acreage and 25\% of production (CSB (China Statistical Bureau), 2014). This large production of potato seems to be difficult to achieve if fertilizer, especially nitrogen (N) fertilizer, is not applied (Milroy et al. 2019). In this sense, reasonable $\mathrm{N}$-fertilizer management is an essential agronomic practice to increase crop yields and to reduce environmental risks derived from fertilizer overuse.

However, optimal $\mathrm{N}$ application rates for potato production vary greatly among the results of case studies in different regions. As a result, the $\mathrm{N}$ application rate required for yield improvement is not easy to predict, and higher amounts of $\mathrm{N}$ fertilizer than required by the crop are usually applied. Excessive $\mathrm{N}$ application rates may decrease the proportion of tubers in total plant dry matter and result in a reduction in tuber yield (Tadesse et al. 2001) while causing great 
environmental concerns. Nitrogen use efficiency (NUE), defined as the ratio of crop yield to amount of $\mathrm{N}$ applied (Moll et al. 1982), can be used to estimate $\mathrm{N}$-fertilizer overuse. High NUE is required to improve sustainability of agricultural systems. However, NUE of global agriculture is estimated to be between 10 and 50\% (Mosier et al. 2004), suggesting that excessive $\mathrm{N}$ application rates may result in serious problems arising from large $\mathrm{N}$ losses and low NUE. Jiao et al. (2013a) reported that the NUE is only $10-32 \%$ for potato produced with the local standard $\mathrm{N}$-fertilizer application rate in the Songnen Plain of China. In addition, a recent study from Gansu Province in northwest China showed that $\mathrm{N}$-fertilizer rates beyond a certain range can lead to a reduction in potato yield and losses of excessive $N$ (Yang et al. 2017). In contrast, a previous study indicated that optimized $\mathrm{N}$ management could increase NUE and N agronomic efficiency in northeast China (Zhao et al. 2016). Thus, the use of a reasonable Nfertilizer input would be an effective method to maintain crop production and increase NUE (Marcello et al. 2018).

Determination of suitable N-fertilizer application rates has become a major topic in the world due to the overuse of $\mathrm{N}$ fertilizer. Although many studies have analyzed the effects of $\mathrm{N}$-fertilizer input on potato production based on field experiments, these results are applicable to specific sites but not to large agro-ecological areas. There has been no specific analysis of the optimal $\mathrm{N}$ application rate at a regional scale for the main potato cultivation regions of China. Based on a thorough literature survey, we created a large dataset of $\mathrm{N}$ application rate, yield, and NUE for four potato cultivation regions of China (Fig. 1b-e) using a meta-analysis method. The yield and NUE of potato were evaluated to provide a theoretical basis for optimizing $\mathrm{N}$-fertilizer management in the potato cultivation region. Therefore, the specific objective of the present study was to determine, at a regional scale, the optimum $\mathrm{N}$-fertilizer rates that would maintain potato yield and increase NUE. We aimed to answer the following questions: (1) What are the optimum $\mathrm{N}$-fertilizer rates in the main potato cultivation regions of China? (2) Does the indigenous N supply affect $\mathrm{N}$ application rate? and (3) What happens to potato yield and NUE if optimum $\mathrm{N}$ is applied at a regional scale?

\section{Materials and methods}

\subsection{Study area}

Potato is the fourth most important food crop in China and widely distributed due to strong adaptability to the growing environment. However, different potato cultivation areas can be designated to match different climate and production conditions of each region. Considering the biological characteristics, meteorological conditions, and geographic locations, China was divided into four different potato cultivation areas: northern region, central region, southwestern region, and southern region (Fig. 1a) (Teng et al. 1989). The northern region is located in the cold temperate zone and the middle temperate zone, which belongs to the single cropping cultivated region with spring planting and autumn harvest. The cool climate, sufficient sunshine, and high diurnal temperature variation are highly suitable for potato growth and development. The cultivation acreage in the northern region accounts for up to $50 \%$ of the total potato acreage in China, and this region is the main potato-producing area in China. The central region is in the warm temperate zone that experiences long summers and high temperatures, and is unfavorable for potato growth. The potato production in the central region accounts for less than $5 \%$ of the total production in China. To avoid high temperature stress, potato in the central region is usually planted in spring and autumn. The southwestern region is located in the subtropical and tropical zone. The complex topography and varying altitude in the southwestern region has formed low-altitude river valleys and high-altitude alpine areas. The mixed cropping potato production in the southwestern region is composed of winter planting in the river valleys and spring planting in the high-altitude alpine areas. The Southern region belongs to the subtropical zone with long summers and warm winters. The major food crop produced in the southern region is rice. Potato in the southern region is generally cultivated on the idle land after harvesting rice in winter since most areas are frost-free year round. The meteorological conditions for the four different potato production regions are presented in Table 1.

\subsection{Collected data}

A search of published papers was performed to collect data on the effects of $\mathrm{N}$ fertilizer on potato yield in China. To include as much research as possible, papers published during 2004-2019 in China were found in the China Knowledge Resource Integrated Database (http://www.cnki.net/) and the Web of Science (http://apps.webofknowledge.com/) using search terms including "potato + nitrogen" and "potato + applying fertilizer." Studies were selected when they met the following criteria: (1) the experiments were carried out in experimental fields, (2) "no $\mathrm{N}$-fertilizer input" was used as a control and various $\mathrm{N}$ application rates were used as other treatments, (3) there was at least one pair of control and treatment data, and (4) all other experimental conditions were consistent in a given experiment except for different $\mathrm{N}$ treatments. Based on the above criteria, a total of 142 published papers (see References of the meta-analysis) (44 papers for the northern region, 17 papers for the central region, 58 papers for the southwestern region, and 23 papers for the southern region) were selected, among which 140 papers were from the China Knowledge Resource Integrated Database, and 2 papers were from the Web of Science. From these papers, 706 observations ( 243 from the northern region, 58 from the central 


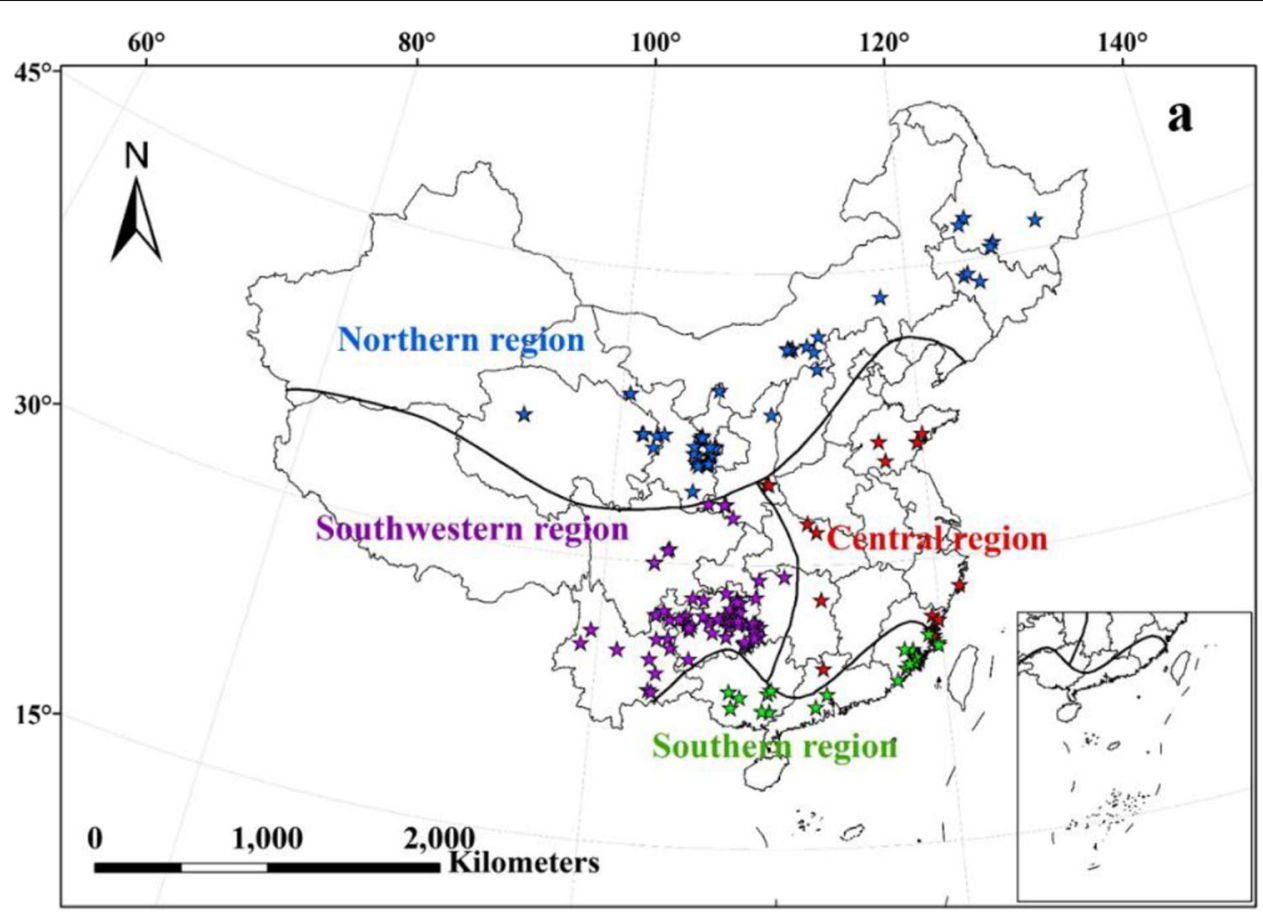

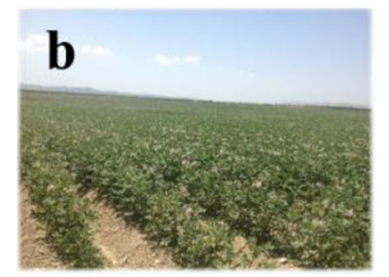

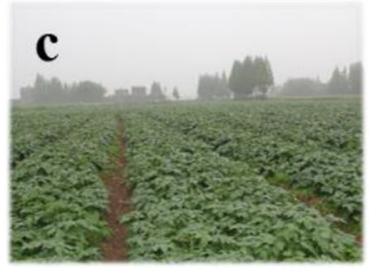

Fig. 1 Location of four potato production regions in China (a), and photographs of typical production fields in each region: northern region (b); central region (c); southwestern region (d); southern region (e). Stars

region, 266 from the southwestern region, and 139 from the southern region) of yield were used in the analysis of potato yield versus $\mathrm{N}$ rate (from zero to various $\mathrm{N}$-fertilizer input). The data obtained in the present study were derived from the experimental sites shown in Fig. 1a.

Chemical fertilizer applications were the focus of the research obtained from the literature search. There were differences in phosphorus and potassium fertilizer inputs between different field experiments, but the phosphorus and potassium fertilizer application rates used between different treatments at a specific site were the same. The phosphorus and potassium rates applied in each given experiment were reasonable based on local production requirements and soil testing, and not limiting potato growth. All field experiments received different levels of urea $(46 \% \mathrm{~N})$, which was viewed as the factor affecting yield variation. In these experiments, potato was planted at the local suitable density at each experimental site. There were differences in climatic conditions and in the physical and chemical properties of the soils at the different field experimental sites. Different potato cultivars suitable for different meteorological conditions were used at the various study locations. Also, irrigation was available for potato

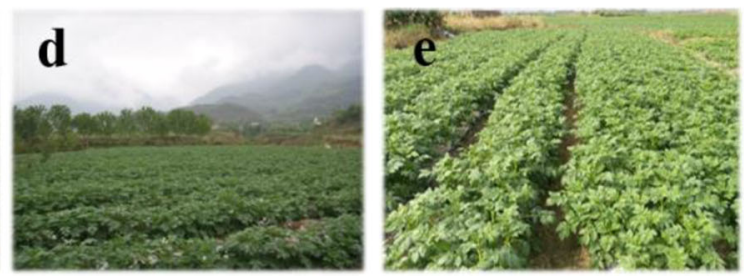

in panel (a) indicate the study sites included in this literature review where primary studies about nitrogen fertilization rates and potato yield have been conducted

growth in around $16 \%$ of study sites. Due to rainfed conditions at most research sites, the difference between rainfed and irrigated areas was not considered. These data came from a wide range of cultivars, fertilizer management practices, climatic conditions, soil types, cultivation practices, and others. Sowing date, harvest date of potato, meteorological conditions, and physical and chemical properties of the soil in the experimental fields in the study areas are shown in Table 1.

\subsection{Calculation of $\mathbf{N}$ fertilizer index}

\subsubsection{Indigenous N supply}

As an indicator of the basic soil fertility, the indigenous $\mathrm{N}$ supply (INS) was regarded as the crop yield obtained in plots where $\mathrm{N}$ was not applied but other nutrients were applied (Wang et al. 2012). INS played an important role in formulating an N-management strategy. Given that INS reflected the inherent soil N-fertility conditions, INS was considered to be an important factor determining reasonable $\mathrm{N}$ rate. Phosphorus and potassium fertilizers were applied at reasonable rates in the field studies reported in the peer-reviewed 
Table 1 Summary of sowing date, harvest date, meteorological conditions, and soil properties using collected data from different potato production regions in China

\begin{tabular}{|c|c|c|c|c|}
\hline & Northern region & Central region & Southwestern region & Southern region \\
\hline Sowing date & $\begin{array}{l}\text { Late April to } \\
\text { mid-May }\end{array}$ & $\begin{array}{l}\text { Early January to } \\
\text { mid-March or August }\end{array}$ & $\begin{array}{l}\text { Late December to late January } \\
\text { of the next year or late } \\
\text { February to mid-March }\end{array}$ & $\begin{array}{l}\text { Mid-November to } \\
\text { mid-December }\end{array}$ \\
\hline Harvest date & $\begin{array}{l}\text { Late August to } \\
\text { mid-October }\end{array}$ & $\begin{array}{l}\text { Mid-May to mid-June } \\
\text { or November }\end{array}$ & $\begin{array}{l}\text { Mid-May to early June or } \\
\text { early July to mid-August }\end{array}$ & $\begin{array}{l}\text { Mid-March to early } \\
\text { April }\end{array}$ \\
\hline Average annual temperature $\left({ }^{\circ} \mathrm{C}\right)$ & -2.4 to 8.5 & $5.8-18.7$ & $10.6-18.1$ & $19.3-24.4$ \\
\hline Average annual precipitation $(\mathrm{mm})$ & $500-1000$ & $400-1500$ & $680-1300$ & $1100-2800$ \\
\hline$>5{ }^{\circ} \mathrm{C}$ accumulated temperature (degree days) & $2000-3500$ & $3500-6500$ & $4000-7500$ & $6500-9500$ \\
\hline Average annual sunshine hours (h) & $2179-2960$ & $1653-2780$ & $1139-2078$ & $1540-1929$ \\
\hline Frost-free period (days) & $105-171$ & $162-286$ & $182-310$ & $305-345$ \\
\hline Available $\mathrm{N}\left(\mathrm{mg} \mathrm{kg}^{-1}\right)$ & $94.1-138.2$ & $96.0-119.0$ & $87.4-108.0$ & $62.8-90.0$ \\
\hline Available $\mathrm{P}\left(\mathrm{mg} \mathrm{kg}^{-1}\right)$ & $7.6-19.3$ & $9.2-20.8$ & $10.7-20.6$ & $9.5-23.1$ \\
\hline Available K (mg kg $\left.{ }^{-1}\right)$ & $118.3-158.4$ & $87.0-150.0$ & $121.8-175.1$ & $76.0-157.0$ \\
\hline Organic matter $\left(\mathrm{g} \mathrm{kg}^{-1}\right)$ & $8.9-23.8$ & $7.8-18.8$ & $7.7-18.4$ & $7.2-18.1$ \\
\hline $\mathrm{pH}$ & $6.5-8.1$ & $5.8-7.1$ & $5.6-6.5$ & $5.2-6.0$ \\
\hline
\end{tabular}

papers we collected data from, and different $\mathrm{N}$-fertilizer application rates comprised the treatments. Soil $\mathrm{N}$ fertility was used to meet the $\mathrm{N}$ demand for potato growth when $\mathrm{N}$ fertilizer was not applied. Therefore, potato yield obtained without $\mathrm{N}$ fertilizer was used as the surrogate for INS $\left(\mathrm{t} \mathrm{ha}^{-1}\right)$.

\subsection{2 $\mathrm{N}$ use efficiency and agronomic efficiency of $\mathrm{N}$}

To assess the use of different levels of $\mathrm{N}$ fertilizer, NUE and agronomic efficiency of $\mathrm{N}$ (AEN) were introduced in the present study. NUE was defined as the ratio of crop yield to amount of $\mathrm{N}$ applied, and indicated agronomic and environmental performance. AEN was defined as the ratio of increase in crop yield between a fertilized plot and a control plot to amount of $\mathrm{N}$ applied, and represented the ability of the crop to produce higher yield in response to added $\mathrm{N}$ fertilizer. NUE $\left(\mathrm{kg} \mathrm{kg}^{-1}\right)$ and AEN $\left(\mathrm{kg} \mathrm{kg}^{-1}\right)$ were therefore calculated as described by Lassaletta et al. (2014) and Rathke and Behrens (2006) as follows:

$$
\begin{aligned}
& N U E=Y_{\mathrm{N}} / F_{\mathrm{N}} \\
& A E N=\left(Y_{\mathrm{N}}-Y_{0}\right) / F_{\mathrm{N}}
\end{aligned}
$$

where $Y_{\mathrm{N}}\left(\mathrm{kg} \mathrm{ha}{ }^{-1}\right)$ is the crop yield in the fertilized plot, $Y_{0}$ $\left(\mathrm{kg} \mathrm{ha}{ }^{-1}\right)$ is the crop yield in the control plot, and $F_{\mathrm{N}}$ $\left(\mathrm{kg} \mathrm{N} \mathrm{ha}^{-1}\right)$ is the total amount of $\mathrm{N}$ applied.

\subsection{Data analysis}

\subsubsection{Statistical evaluation of regression models}

To adequately represent the possible shape of the yield- $\mathrm{N}$ rate relationship, the response of potato yields to $\mathrm{N}$-fertilizer rate was described using linear, exponential, quadratic, and linear-plus-plateau models. In the regression models, $\mathrm{N}$ fertilizer rate $(X)$ was used in each field experiment as the independent variable, and the corresponding potato yield $(Y)$ was the dependent variable. For the linear model, $Y$ increased linearly with increasing $X$. For the exponential model, $Y$ increased exponentially with increasing $X$. For the quadratic model, $Y$ increased with increasing $X$ at relatively low $X$ values, and then decreased with increasing $X$ after reaching a critical $X$ value. For the linear-plusplateau model, the data points were divided into two sets. In the first set, $Y$ increased linearly with increasing $X$ until $Y$ reached a maximum value at a critical $X$ value. In the second set of data points, additional increases in $X$ beyond the critical $X$ value did not produce any further increase in $Y$.

Regression analyses produced coefficients of determination $\left(R^{2}\right), F$ values, and $P$ values used to interpret the yield$\mathrm{N}$ rate relationship. In addition, root mean square error (RMSE) values were analyzed in order to assess performance of the regression models calculated from differences between simulated and observed yields.

The linear model was computed as

$Y=m X+n$

where $m$ is the coefficient of the linear function and $n$ is the linear intercept.

The exponential model was computed as

$Y=u e^{v X}$

where $e$ is a mathematical constant, and $u$ and $v$ are fitting coefficients. 
The quadratic model was computed as

$$
\begin{aligned}
& Y=a X^{2}+b X+c \\
& X_{\max }=-b /(2 a), Y_{\max }=\left[-b+\left(b^{2}-4 a c\right)^{0.5}\right] /(2 a)
\end{aligned}
$$

where $a$ and $b$ are the fitting coefficients of the quadratic function, and $c$ is the quadratic intercept.

The linear-plus-plateau model was computed as

$\left\{\begin{array}{c}\mathrm{Y}=\mathrm{kX}+\mathrm{d}, \text { if } \mathrm{X}<X_{\mathrm{opt}} \\ \mathrm{Y}=Y_{\mathrm{max}}, \text { if } \mathrm{X} \geq X_{\mathrm{opt}}\end{array}\right.$

where $k$ is the coefficient of the linear function, $d$ is the linear intercept, and $X_{\text {opt }}$ is the critical N rate that occurs at the intersection of the linear response and the plateau line that indicates maximum yield $\left(Y_{\max }\right)$.

The RMSE was computed using the following formula:

$\operatorname{RMSE}(\%)=\frac{100}{\overline{\mathrm{O}}} \times \sqrt{\frac{\sum_{i=1}^{n}\left(O_{i}-P_{i}\right)^{2}}{n}}$

where $n$ is the number of observed and simulated data pairs, $O_{i}$ and $P_{i}$ are observed and simulated values, respectively, and $\overline{\mathrm{O}}$ is the average observed value. Smaller RMSE values indicate better agreement between simulated and observed values.

Statistical evaluation of the four different regression models in the four potato cultivation regions is shown in Table 2. Higher $R^{2}$ and smaller RMSE values were the criteria used for selecting a reasonable regression model. The $R^{2}$ values of the quadratic and linear-plus-plateau models were higher than those of the linear and exponential models. In addition, the quadratic and linear-plus-plateau models had smaller RMSE values than the linear and exponential models. The differences in $R^{2}$ and RMSE values between the quadratic model and the linear-plus-plateau model were small. Compared with the linear and exponential models, the quadratic and linear-plus-plateau models better described response curves for the yield-N rate relationship, thereby providing reasonable estimates of $\mathrm{N}$-fertilizer input. We compared the results of these two models to identify the optimum $\mathrm{N}$-fertilizer rates (i.e., recommended $\mathrm{N}$-fertilizer rates) required to obtain high NUE and maintain potato yield.

\subsubsection{Statistical analysis}

The assumptions of normality and homoscedasticity of the residuals were tested using the Shapiro-Wilk test and the Levene test, respectively. The original NUE and AEN data were not normally distributed. Therefore, we performed a logarithmic transform on the NUE data and a square root transform on the AEN data. One-way ANOVA was used to compare the INS between different regions using SPSS 22.0 (https://www.ibm.com/products/spss-statistics). When the
ANOVA was significant, means were compared by least significant difference (LSD) calculated at $p<0.05$. An exponential equation was used to simulate NUE and AEN responses to N-fertilizer rate using SPSS 22.0. To establish the best curve defining the response of yield to $\mathrm{N}$-fertilizer rate, different regression models were applied. The linear, exponential, and quadratic relationships between yield and $\mathrm{N}$ rate were quantified using SPSS 22.0, and the linear-plus-plateau equation for the yield-N rate relationship was determined with the SAS System 9.2 (https://www.sas.com/). Figures and tables were made using Microsoft Excel software (https:// www.microsoft.com/en-us/). The map figure was created with ArcGis 10.2 software (https://www.esri.com/).

\section{Results and discussion}

\subsection{Comparison of models and determination of optimum $\mathrm{N}$ rate}

The effect of different $\mathrm{N}$-fertilizer application rates on potato yield was analyzed in the four producing regions of China using a quadratic model and a liner-plus-plateau model (Fig. 2). The northern region showed the greatest mean yield followed by the central, southern, and southwestern regions, respectively. When using the quadratic model, maximum yields were obtained when critical $\mathrm{N}$-fertilizer rates were 178, 251, 217, and $218 \mathrm{~kg} \mathrm{~N} \mathrm{ha}^{-1}$ in the northern, central, southwestern, and south regions, respectively, whereas the linear-plus-plateau model estimated critical $\mathrm{N}$-fertilizer rates of $115,150,120$, and $126 \mathrm{~kg} \mathrm{~N} \mathrm{ha}^{-1}$ for maximum yields in the northern, central, southwestern, and south regions, respectively. The maximum yield estimated by the quadratic model was 4.33-7.06\% greater than that predicted by the linear-plus-plateau model in the four regions. However, $\mathrm{N}$ application rates to obtain these maximum estimated yields based on the quadratic model were 54.78, $67.33,80.83$, and $73.02 \%$ higher than those calculated by the linear-plus-plateau model for the northern, central, southwestern, and south regions, respectively. Given these results, we could conclude that use of the linear-plus-plateau model to estimate the optimum $\mathrm{N}$ rate could prevent $\mathrm{N}$-fertilizer overuse without losing a significant amount of yield. Consequently, we used this model to estimate recommended $\mathrm{N}$-fertilizer rates, which were $115,150,120$, and $126 \mathrm{~kg} \mathrm{~N} \mathrm{ha}^{-1}$ for the northern, central, southwestern, and southern regions, respectively.

Compared with the quadratic model, the linear-plus-plateau model produced lower optimum $\mathrm{N}$ rates without significant yield losses. By comparing the results of the quadratic and linear-plusplateau models, Liu et al. (2016) selected the linear-plus-plateau model to determine optimal $\mathrm{N}$ rate. Li et al. (2019) also reported that the linear-plus-plateau model was used to identify recommended $\mathrm{N}$ input. In addition, the optimum $\mathrm{N}$ rates estimated by the linear-plus-plateau model in our study were similar to the 
Table 2 Statistical evaluation of the different regression models

\begin{tabular}{|c|c|c|c|c|c|}
\hline Regions & Statistics & Linear model & Exponential model & Quadratic model & Linear-plus-plateau model \\
\hline \multirow[t]{4}{*}{ Northern region } & RMSE & $24.55 \%$ & $25.02 \%$ & $22.05 \%$ & $22.67 \%$ \\
\hline & $R^{2}$ & 0.1523 & 0.1557 & 0.3162 & 0.2775 \\
\hline & $F$ value & 43.29 & 44.45 & 55.49 & 46.09 \\
\hline & $P$ value & $<0.001$ & $<0.001$ & $<0.001$ & $<0.001$ \\
\hline \multirow[t]{4}{*}{ Central region } & RMSE & $27.66 \%$ & $28.55 \%$ & $26.13 \%$ & $25.62 \%$ \\
\hline & $R^{2}$ & 0.2668 & 0.2773 & 0.3637 & 0.3710 \\
\hline & $F$ value & 20.38 & 21.49 & 15.72 & 16.22 \\
\hline & $P$ value & $<0.001$ & $<0.001$ & $<0.001$ & $<0.001$ \\
\hline \multirow[t]{4}{*}{ Southwestern region } & RMSE & $25.53 \%$ & $26.09 \%$ & $24.39 \%$ & $24.07 \%$ \\
\hline & $R^{2}$ & 0.1772 & 0.1980 & 0.2736 & 0.2688 \\
\hline & $F$ value & 56.86 & 65.20 & 49.54 & 48.35 \\
\hline & $P$ value & $<0.001$ & $<0.001$ & $<0.001$ & $<0.001$ \\
\hline \multirow[t]{4}{*}{ Southern region } & RMSE & $25.92 \%$ & $26.60 \%$ & $23.81 \%$ & $24.10 \%$ \\
\hline & $R^{2}$ & 0.1783 & 0.2077 & 0.3093 & 0.2892 \\
\hline & $F$ value & 29.73 & 35.91 & 30.45 & 27.66 \\
\hline & $P$ value & $<0.001$ & $<0.001$ & $<0.001$ & $<0.001$ \\
\hline
\end{tabular}

$R M S E$ root mean square error, $R^{2}$ coefficient of determination, $P$ value significance of the regression

results reported by Liu et al. (2010a). Therefore, the linear-plusplateau model should be considered a feasible option to estimate reasonable $\mathrm{N}$-fertilizer application rates.

\subsection{Indigenous $\mathbf{N}$ supply in four production regions}

We calculated INS to test its influence on the optimum Nfertilizer rate for each region. The national mean INS was $18.98 \mathrm{t} \mathrm{ha}^{-1}$, ranging from 5.90 to $30.77 \mathrm{t} \mathrm{ha}^{-1}$ (Fig. 3a). The mean INS values were $20.95,18.08,17.70$, and $17.90 \mathrm{t} \mathrm{ha}^{-1}$ in the northern, central, southwestern, and south regions, respectively (Fig. 3b). We predicted that lower $\mathrm{N}$ input would be needed to obtain target yield under higher INS conditions. The mean INS of the Northern region was significantly higher than that in the other regions (Fig. 3b). Correspondingly, this region had the lowest optimum $\mathrm{N}$ rate and highest estimated yield (Fig. 2). This fact suggests that INS plays an important role in the determination of optimum $\mathrm{N}$-fertilizer rate and final yield. It appears that when INS is high, less $\mathrm{N}$ fertilization is needed to produce a certain yield. A similar conclusion was reached by Jing et al. (2007) regarding the role of INS for two rice cultivars. They showed that a higher INS was related to a lower $\mathrm{N}$ application rate. Therefore, INS might be an important factor affecting the determination of optimum $\mathrm{N}$-fertilizer rate.

\section{3 $\mathrm{N}$ use efficiency and agronomic efficiency of $\mathrm{N}$ under different $\mathbf{N}$ input}

To establish response curves of NUE and AEN to Nfertilizer rate, the trends in NUE and AEN under different
$\mathrm{N}$ inputs were analyzed (Fig. 4). Both NUE and AEN decreased with increasing $\mathrm{N}$ rates, with average values of $207.38,170.70,187.87$, and $152.89 \mathrm{~kg} \mathrm{~kg}^{-1}$ for NUE, and $51.83,45.02,47.35$, and $42.84 \mathrm{~kg} \mathrm{~kg}^{-1}$ for AEN in the northern, central, southwestern, and south regions, respectively. van Bueren and Struik (2017) reported that NUE was relatively high at low $\mathrm{N}$ levels and decreased with increasing $\mathrm{N}$-fertilizer rates. High NUE was probably due to high green leaf area index and leaf $\mathrm{N}$ concentration, resulting in greater accumulated dry matter and greater $\mathrm{N}$ uptake from the soil (Qiang et al. 2019). In addition, well-managed systems can result in high AEN at low N-fertilizer rates (Dobermann 2007). Synchronizing fertilizer-N supply with crop $\mathrm{N}$ demand through reasonable $\mathrm{N}$-fertilizer management will improve both NUE and AEN.

\subsection{Yield and $\mathrm{N}$ use efficiency of the recommended $\mathrm{N}$ rate}

$\mathrm{N}$-fertilizer inputs above and below the recommended $\mathrm{N}$ rate for each region were viewed as high $\mathrm{N}$ rates and low $\mathrm{N}$ rates, respectively. The $\mathrm{N}$-fertilizer rate applied in $77,69,68$, and $67 \%$ of various $\mathrm{N}$ treatments at all sites exceeded the recommended $\mathrm{N}$ input, and the remaining 23, 31, 32, and $33 \%$ of the cases received $\mathrm{N}$-fertilizer rates that were lower than the recommended $\mathrm{N}$ rate in the northern, central, southwestern, and south regions, respectively. To compare differences in yield, NUE, and AEN between low, recommended, and high $\mathrm{N}$ rates, the corresponding yields at low and high $\mathrm{N}$ rates were calculated based on the linear-plus-plateau model. The NUE 


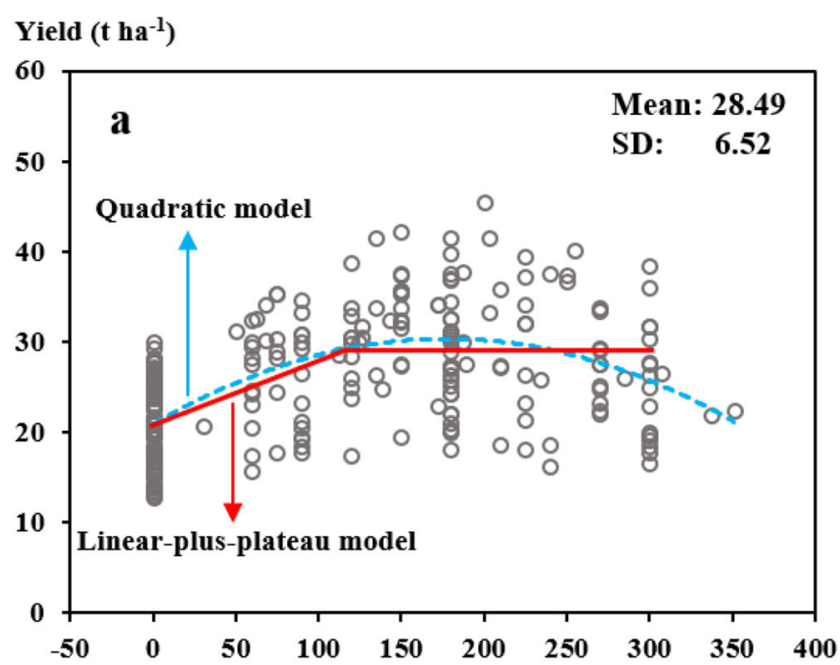

Yield (t ha-1)
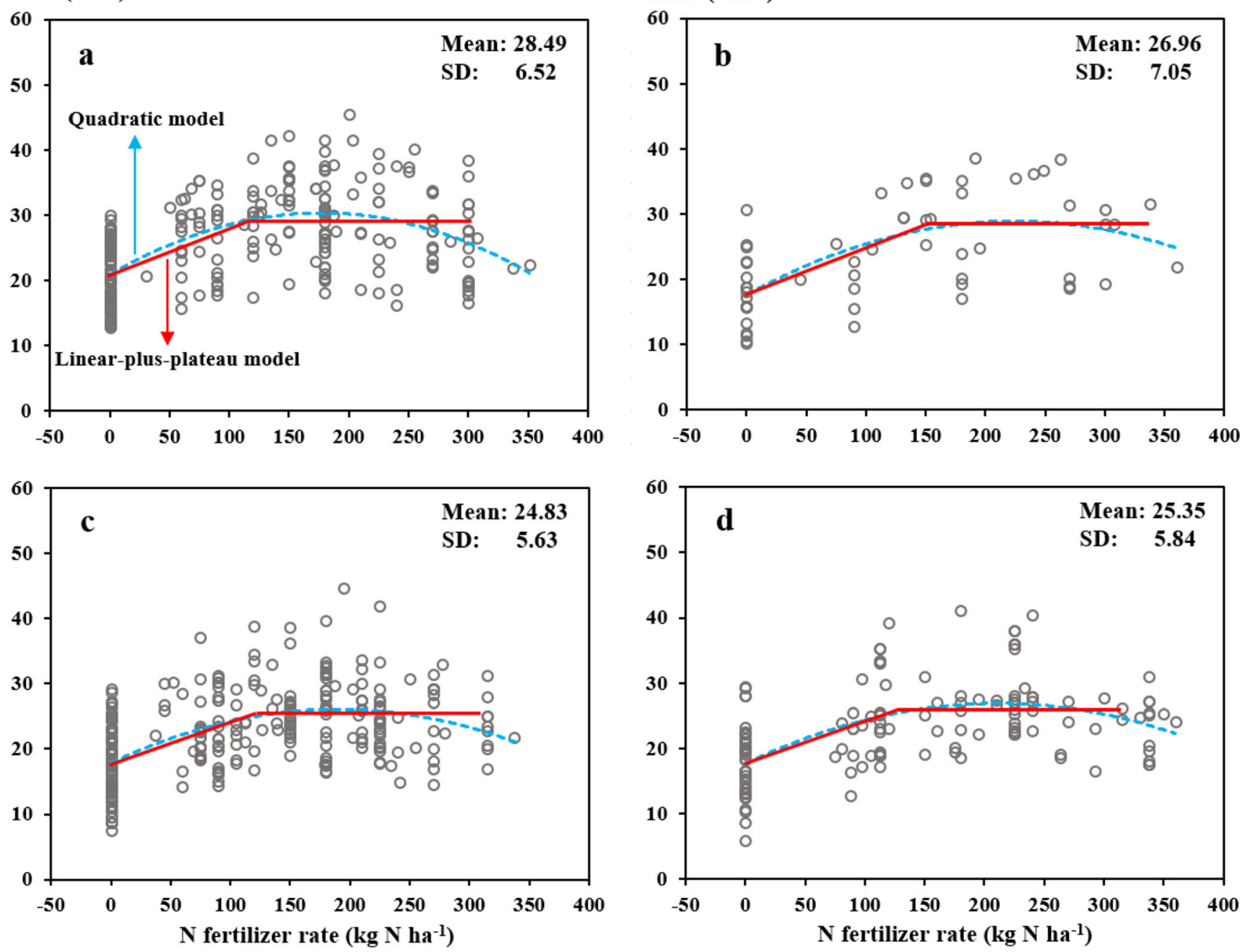

Fig. 2 Yield as a function of $\mathrm{N}$ fertilizer rate in four potato production regions in China. a Northern region; b central region; c southwestern region; $\mathbf{d}$ southern region. Mean, the average value of potato yield in the fertilized plot; SD, standard deviation. Quadratic model: $y=-$ $0.0003 x^{2}+0.1066 x+20.902$ (northern region); $y=-0.0002 x^{2}+$ $0.1005 x+17.637$ (central region); $y=-0.0002 x^{2}+0.0869 x+17.842$

(or AEN) values at low, recommended, and high $\mathrm{N}$ rates were also calculated using the exponential relationships between the $\mathrm{N}$ rate and NUE (or AEN).

Compared with the yield of the low $\mathrm{N}$ rate, the recommended $\mathrm{N}$ rate increased yield by $10.77,14.70,10.13$, and $5.95 \%$ in the northern, central, southwestern, and south regions, respectively (Fig. 5). Van Dingenen et al. (2019) reported that limited $\mathrm{N}$ availability produced lower potato yield than optimal $\mathrm{N}$ availability due to a reduced number of tubers. Low $\mathrm{N}$ input might deplete the soil $\mathrm{N}$ pool resulting in not enough $\mathrm{N}$ to meet the demand for crop growth and ultimately reduced yield (Vrignon-Brenas et al. 2019). Although yields at the recommended $\mathrm{N}$ rate were comparable with yields at high $\mathrm{N}$ rate in all regions, the recommended $\mathrm{N}$ rate increased NUE by 64.82 , $48.60,54.97$, and $81.67 \%$, and improved AEN by 72.90 ,

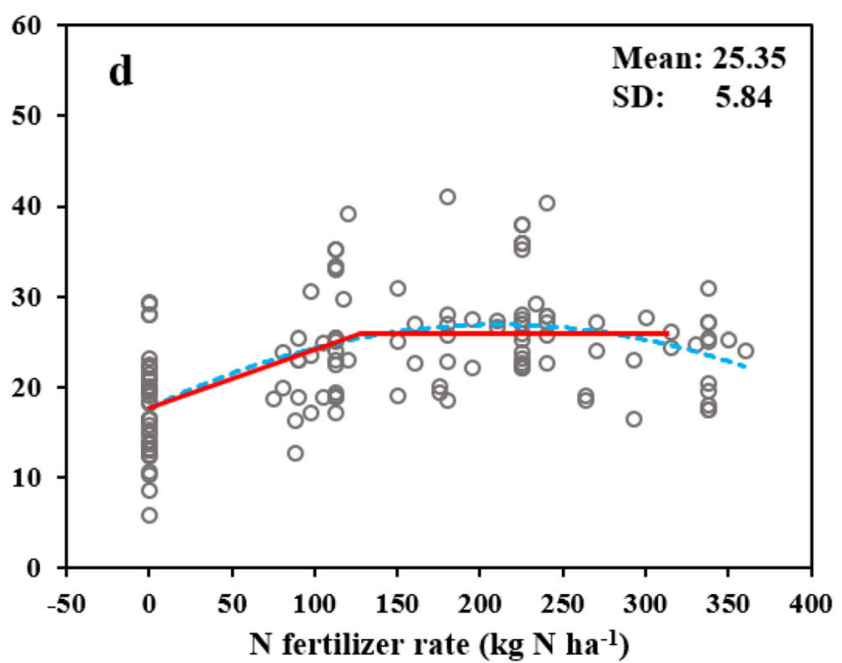

(southwestern region); $y=-0.0002 x^{2}+0.0873 x+17.670$ (southern region). Linear-plus-plateau model: $y=0.0701 x+21.0488 x<115, y=$ $29.11 x \geq 115$ (northern region); $y=0.0708 x+17.6635 x<150, y=$ $28.27 x \geq 150$ (central region); $y=0.0634 x+17.8733 x<120, y=$ $25.48 x \geq 120$ (southwestern region); $y=0.0650 x+17.7001 x<126, y=$ $25.91 x \geq 126$ (southern region)

$17.12,39.14$, and $60.93 \%$ for the northern, central, southwestern, and south regions, respectively (Fig. 5), revealing that high $\mathrm{N}$-fertilizer application rates led to a waste of the $\mathrm{N}$ resource. Shillito et al. (2009) analyzed the spatial response of potato yield to $\mathrm{N}$ rate and indicated that additional $\mathrm{N}$ input above the recommended $\mathrm{N}$ rate would result in excessive $\mathrm{N}$ loss from the soil. A reasonable $\mathrm{N}$ rate should be used to ensure high yield and NUE. A low N rate would limit potential yield increase, while a high $\mathrm{N}$ rate would lead to $\mathrm{N}$ surplus and aggravate environmental risk. In the present study, the recommended $\mathrm{N}$ rate achieved the two goals of maintaining potato yield and improving NUE. Use of the recommended $\mathrm{N}$ rate to maintain potato yield while improving NUE could be formulated as a general management proposal at a regional scale. 


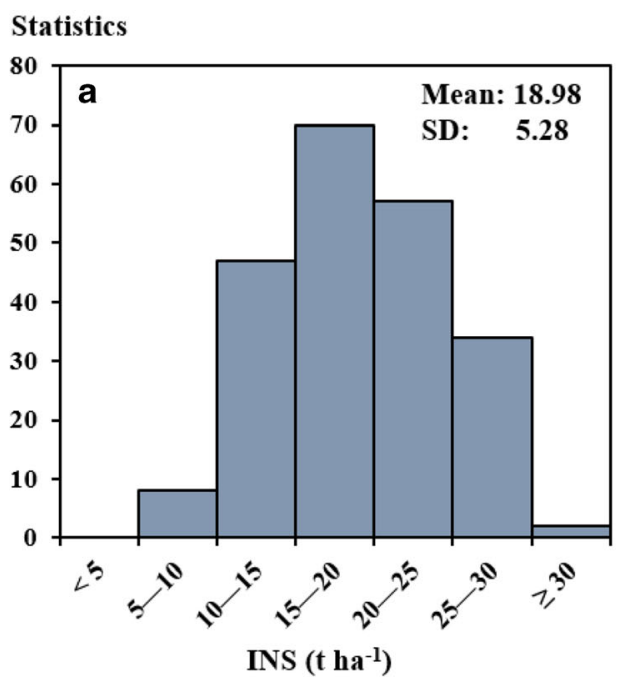

Fig. 3 Frequency distribution of indigenous N supply (INS) from all study regions across China (a) and comparison of INS between different potato production regions in China (b). Mean, the average value of INS across all regions; SD, standard deviation. NR, northern region; CR, central region; SWR, southwestern region; SR, southern region. Cross and solid lines indicate mean and median value, respectively. The box boundaries indicate the upper and lower quartiles,

\subsection{Uncertainty of optimum $\mathbf{N}$ rate for different research targets and specific sites}

When optimizing $\mathrm{N}$-fertilizer management, different research targets can result in different optimum $\mathrm{N}$ rates. Ying et al. (2017) reported that the optimum $\mathrm{N}$ rates needed to maximize values of yield, private profitability, ecological benefits, and social benefits were not the same. Economic income and environmental costs are sometimes considered when determining reasonable $\mathrm{N}$ application rates. Because these indicators were calculated by yield directly or indirectly, maximizing crop yield was generally regarded as the number one goal when evaluating a reasonable $\mathrm{N}$ application rate (Vos 2009). In the present study, the optimum $\mathrm{N}$ rate would definitely be different from that identified by the yield if the research target was to pursue economic income, ecological benefit, or other goals.

Reference $\mathrm{N}$ application rates can be determined from a literature survey in order to improve $\mathrm{N}$-fertilizer management for a large-scale region. However, reasonable $\mathrm{N}$ inputs identified based on results obtained from studies conducted at a specific site might not be applicable across a large region. Results obtained from several sites across a region could provide relatively reliable guidance for regional $\mathrm{N}$ management (Zhang et al. 2018). In our study, estimated $\mathrm{N}$ rates were obtained from various field experiments that considered the effects of graded applications of $\mathrm{N}$ fertilizer, and not from farmers' typical N-fertilizer application rates, which basically represented the reference $\mathrm{N}$ levels at a regional scale. Due to differences in soil and climate conditions between various sites, the $\mathrm{N}$ input appropriate for a specific site should be
INS (t ha-1)

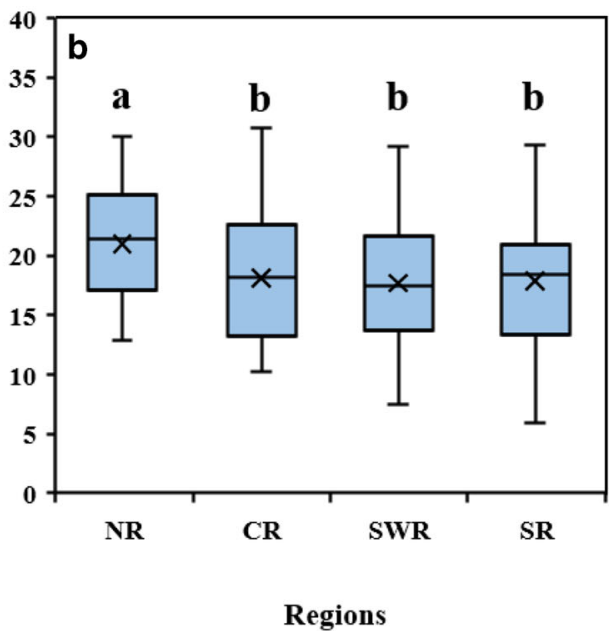

and the whisker caps indicate the 90th and 10th percentiles. Different lower case letters in panel (b) indicate significant differences in mean INS between regions at $P<0.05$. Mean INS values between regions are compared according to one-way ANOVA: $F=6.46, P<0.001, \mathrm{LSD}_{\text {(NR- }}$ $\mathrm{CR})=2.56, \mathrm{LSD}_{(\mathrm{NR}-\mathrm{SWR})}=1.59, \mathrm{LSD}_{(\mathrm{NR}-\mathrm{SR})}=1.94, \mathrm{LSD}_{(\mathrm{CR}-\mathrm{SWR})}=2.57$, $\mathrm{LSD}_{(\mathrm{CR}-\mathrm{SR})}=2.80, \mathrm{LSD}_{(\mathrm{SWR}-\mathrm{SR})}=1.95$

adjusted to match local conditions (Morteza et al. 2018). In addition to uncontrollable factors (such as climate), Nfertilizer input should consider potato varieties and management practices used. Modern potato varieties usually have higher recommended $\mathrm{N}$-fertilizer application rates than heritage varieties (Fandika et al. 2016). Using optimized management practices could reduce the $\mathrm{N}$-fertilizer application rate needed to achieve the target yield. Regulating site-specific $\mathrm{N}$ application rates is essential when considering different varieties and management practices. However, unreasonable $\mathrm{N}$-fertilizer applications are usually applied in most of the regions, and these rates are based on experience rather than on crop growth requirements for $\mathrm{N}$ (Peng et al. 2010). The overuse of $\mathrm{N}$ fertilizer generally does not lead to a significant increase in yield at sites with suitable production conditions and advanced management practices, but can cause great environmental problems. Sites with high $\mathrm{N}$ input should be required to reduce $\mathrm{N}$ application rate as much as possible. The negative impact of insufficient $\mathrm{N}$ input on yield should also not be ignored. To avoid yield loss, sites with low INS or unsuitable climate conditions should reasonably increase $\mathrm{N}$ input.

\section{Conclusions}

The relationship between potato yield and N-fertilizer application rate was estimated to determine the optimum $\mathrm{N}$ rate at a regional scale, which were $115,150,120$, and $126 \mathrm{~kg} \mathrm{~N} \mathrm{ha}^{-1}$ for the northern, central, southwestern, and southern regions of China, respectively. We found that $\mathrm{N}$ use efficiency and 

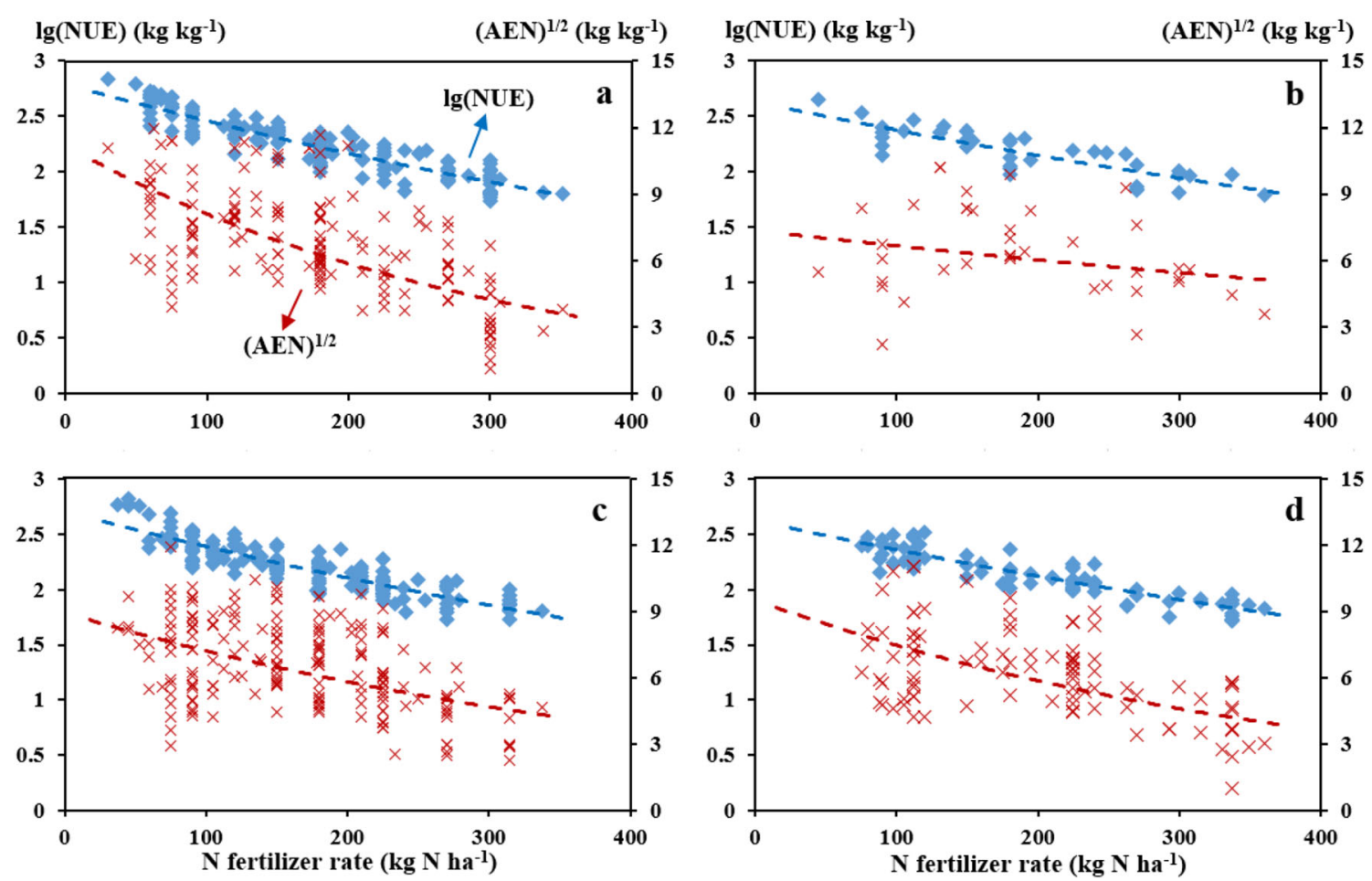

Fig. 4 The N use efficiency (NUE) and agronomic efficiency of N (AEN) at different $\mathrm{N}$ fertilizer rates in four potato production regions in China. a Northern region; b central region; c southwestern region; d southern region. Regression equations for $\lg$ (NUE): $y=2.79 e^{-0.001 x} R^{2}=$ $0.8190 * * * F=723.87$ (northern region); $y=2.63 e^{-0.001 x} R^{2}=$ $0.7086 * * * F=89.97$ (central region); $y=2.71 e^{-0.001 x} R^{2}=0.7939 * * *$ $F=716.43$ (southwestern region); $y=2.62 e^{-0.001 x} R^{2}=0.8061 * * * F=$

403.19 (southern region). Regression equations for $(\mathrm{AEN})^{1 / 2}: y=$ $11.21 e^{-0.003 x} R^{2}=0.3930 * * * F=103.59$ (northern region); $y=$ $7.36 e^{-0.001 x} R^{2}=0.0580 F=2.28$ (central region); $y=8.96 e^{-0.002 x} R^{2}=$ $0.2260 * * * F=54.32$ (southwestern region); $y=9.53 e^{-0.002 x} R^{2}=$ $0.3042 * * * F=42.41$ (Southern region). $* * *$ indicates significance at the 0.001 level

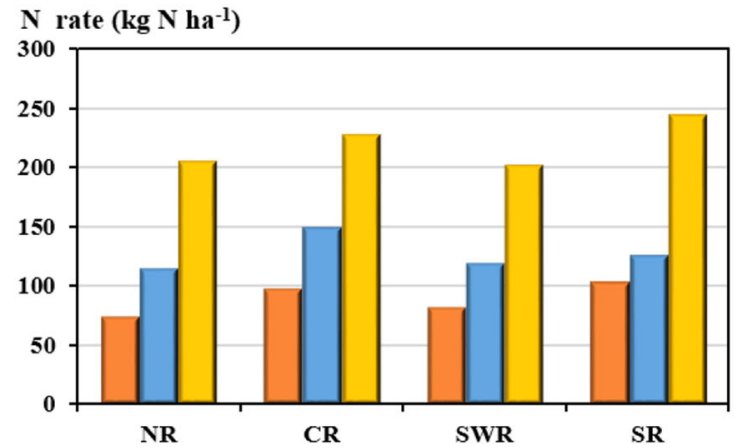

Yield (kg ha-1)
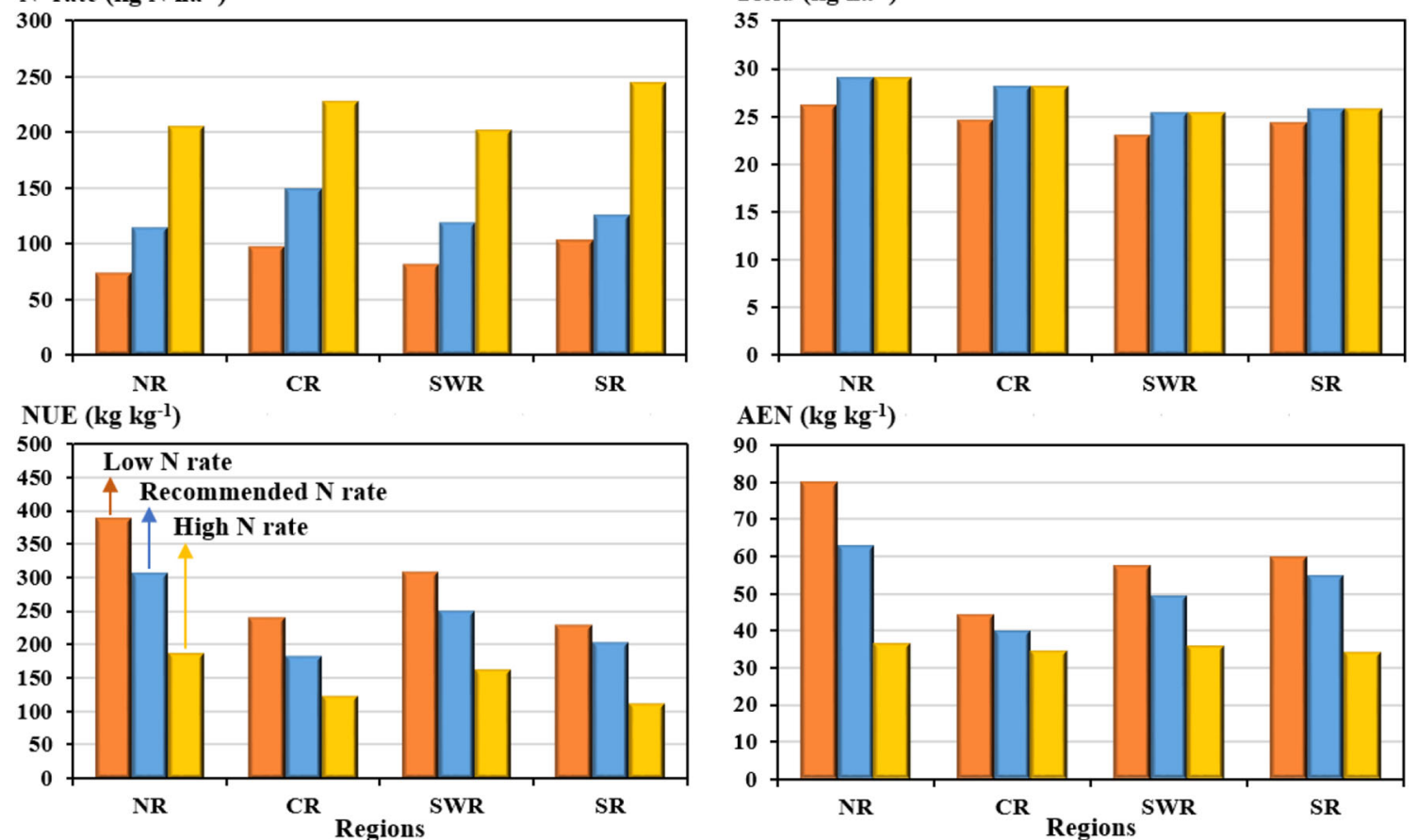

Fig. 5 The yield, $\mathrm{N}$ use efficiency (NUE), and agronomic efficiency of $\mathrm{N}$ (AEN) under three $\mathrm{N}$ rate levels in the northern (NR), central (CR), southwestern (SWR), and southern (SR) potato production regions of China 
agronomic efficiency could be improved without potato yield losses based on the estimated $\mathrm{N}$ rate. $\mathrm{N}$-fertilizer application rates below the recommended $\mathrm{N}$ rate resulted in yield losses of $5.95-14.70 \%$. Yields obtained under the recommended $\mathrm{N}$ rate were equivalent to yields at high $\mathrm{N}$ rates. However, using the recommended $\mathrm{N}$ rate increased $\mathrm{N}$ use efficiency by 48.60 $81.67 \%$ and agronomic efficiency of $\mathrm{N}$ by $17.12-72.90 \%$. As a result, potato yields may not be significantly increased when excessively high $\mathrm{N}$-fertilization rates are used, and moderate reductions in $\mathrm{N}$-fertilizer input should be considered. $\mathrm{N}$ fertilizer rate should be increased in areas with poor soil fertility or unsuitable climate conditions in order to reduce potato yield losses. This evaluation of regional $\mathrm{N}$-fertilizer application rates may be a useful reference providing a theoretical basis for how to maintain crop production while optimizing $\mathrm{N}$-fertilizer management. These results are of great significance for recommending production practices resulting in sustainable development of agricultural systems.

Acknowledgments The authors thank Ning Luo for help on analyzing the study data. The authors wish to thank Jiongchao Zhao for advice on revising the manuscript. The authors thank Dr. David C. Nielsen (www. aereainc.com) for correcting the English. The authors are also very grateful to the journal's editors and two anonymous reviewers.

Author contributions Conceptualization: Q.Q.C. and J.G.L. Methodology: C.W. and X.Y.S. Validation: J.G.L. and S.L. Formal analysis: C.W. and H.D.Z. Investigation: C.W., X.Y.S., and S.L. Writingoriginal draft: C.W. and H.D.Z. Writing - review and editing: C.W., Q.Q.C., and H.D.Z. Supervision: Q.Q.C. and F.C. Funding acquisition: Q.Q.C. and F.C.

Funding This research was supported by the National Key Research and Development Program of China (2016YFD0300201), and the National Natural Science Foundation of China (31871581).

Data availability The datasets analyzed during the current study are available from the corresponding author on reasonable request.

\section{Compliance with ethical standards}

Conflict of interest The authors declare that they have no conflict of interest.

\section{References}

CSB (China Statistical Bureau) (2014) China statistical year book 2014. China Statistics Press, Beijing http://www.stats.gov.cn/tjsj/ndsj/ 2014/indexch.htm

Dobermann A (2007) Nutrient use efficiency-measurement and management. In: Krauss A et al (eds) Fertilizer best management practice: general principles, strategy for their adoption and voluntary initiatives vs. regulations. IFA Int. Worksh. On fertilizer best management practices, Brussels, Belgium. 7-9 March 2007. Int. Fert. Ind. Assoc., Paris, France, pp 1-28

Fandika IR, Kemp PD, Millner JP, Horne D, Roskruge N (2016) Irrigation and nitrogen effects on tuber yield and water use efficiency of heritage and modern potato cultivars. Agric Water Manage 170:148-157. https://doi.org/10.1016/j.agwat.2015.10.027

Godfray HCJ, Beddington JR, Crute IR, Haddad L, Lawrence D, Muir JF, Pretty J, Robinson S, Thomas SM, Toulmin C (2010) Food security: the challenge of feeding 9 billion people. Science 327 : 812-818. https://doi.org/10.1126/science.1185383

Jiao F, Wu JH, Yu LH, Zhai RC (2013a) ${ }^{15} \mathrm{~N}$ tracer technique analysis of the absorption and utilisation of nitrogen fertiliser by potatoes. Nutr Cycl Agroecosyst 95:345-351. https://doi.org/10.1007/s10705013-9567-8

Jing Q, Bouman BAM, Hengsdijk H, Van Keulen H, Cao W (2007) Exploring options to combine high yields with high nitrogen use efficiencies in irrigated rice in China. Eur J Agron 26:166-177. https://doi.org/10.1016/j.eja.2006.09.005

Lassaletta L, Billen G, Grizzetti B, Anglade J, Garnier J (2014) 50 year trends in nitrogen use efficiency of world cropping systems: the relationship between yield and nitrogen input to cropland. Environ Res Lett 9:105011. https://doi.org/10.1088/1748-9326/9/10/105011

Li S, Lei YD, Zhang YY, Liu JG, Shi XY, Jia H, Wang C, Chen F, Chu QQ (2019) Rational trade-offs between yield increase and fertilizer inputs are essential for sustainable intensification: a case study in wheat-maize cropping systems in China. Sci Total Environ 679: 328-336. https://doi.org/10.1016/j.scitotenv.2019.05.085

Liu HS, Yang XD, Zhang XH, Fu GD (2010a) Optimization of fertilization for potato production in semi-arid areas. Chin Potato J 24:357359. https://doi.org/10.3969/j.issn.1672-3635.2010.06.011

Liu H, Wang ZH, Yu R, Li FC, Li KY, Cao HB, Yang N, Li MH, Dai J, Zan YL, Li Q, Xue C, He G, Huang DL, Huang M, Liu JS, Qiu WH, Zhao HB, Mao H (2016) Optimal nitrogen input for higher efficiency and lower environmental impacts of winter wheat production in China. Agric Ecosyst Environ 224:1-11. https://doi.org/10.1016/j. agee.2016.03.022

Marcello G, Giacomo T, Beatrice F, Paolo B (2018) Sustainable management of nitrogen nutrition in winter wheat through temporary intercropping with legumes. Agron Sustain Dev 38:31. https://doi. org/10.1007/s13593-018-0509-3

Milroy SP, Wang P, Sadras VO (2019) Defining upper limits of nitrogen uptake and nitrogen use efficiency of potato in response to crop $\mathrm{N}$ supply. Field Crop Res 239:38-46. https://doi.org/10.1016/j.fcr. 2019.05.011

Moll RH, Kamprath EJ, Jackson WA (1982) Analysis and interpretation of factors which contribute to efficiency of nitrogen utilization. Agron J 74:562-564. https://doi.org/10.2134/agronj1982. $00021962007400030037 \mathrm{x}$

Morteza M, Elizabeth P, Guillaume J, Didier A, Geng XY, Nicolas Tremblay T, Zhang FS (2018) New model-based insights for strategic nitrogen recommendations adapted to given soil and climate. Agron Sustain Dev 38:36. https://doi.org/10.1007/s13593-0180505-7

Mosier AR, Syers JK, Freney JR (2004) Nitrogen fertilizer: an essential component of increased food, feed, and fiber production. In: Mosier AR et al (eds) Agriculture and the nitrogen cycle: assessing the impacts of fertilizer use on food production and the environment. Island Press, Washington, DC, pp 3-15

Peng SB, Buresh RJ, Huang JL, Zhong XH, Zou YB, Yang JC, Wang GH, Liu YY, Hu RF, Tang QY, Cui KH, Zhang FS, Dobermann A (2010) Improving nitrogen fertilization in rice by site-specific N management. A review. Agron Sustain Dev 30:649-656. https:// doi.org/10.1051/agro/2010002

Qiang SC, Zhang Y, Fan JL, Zhang FC, Xiang YZ, Yan SC, Wu Y (2019) Maize yield, rainwater and nitrogen use efficiency as affected by maize genotypes and nitrogen rates on the loess plateau of China. Agric Water Manage 213:996-1003. https://doi.org/10.1016/j. agwat.2018.12.021

Rathke GW, Behrens T, Diepenbrock W (2006) Integrated nitrogen management strategies to improve seed yield, oil content and nitrogen 
efficiency of winter oilseed rape (Brassica napus, L.): a review. Agric Ecosyst Environ 117:80-108. doi: https://doi.org/10.1016/j. agee.2006.04.006

Shillito RM, Timlin DJ, Fleisher D, Reddy VR, Quebedeaux B (2009) Yield response of potato to spatially patterned nitrogen application. Agric Ecosyst Environ 129:107-116. https://doi.org/10.1016/j.agee. 2008.07.010

Tadesse M, Lommen WJM, Struik PC (2001) Effects of nitrogen pretreatment of transplants from in vitro produced potato plantlets on transplant growth and yield in the field. Njas-Wagen J Life Sci 49: 67-79. https://doi.org/10.1016/S1573-5214(01)80016-6

Teng ZF, Zhang C, Wang YZ (1989) Study on China's potato-cultivation divisions. Sci Agric Sin 22:35-44

van Bueren ETL, Struik PC (2017) Diverse concepts of breeding for nitrogen use efficiency. A review. Agron Sustain Dev 37:50. https://doi.org/10.1007/s13593-017-0457-3

Van Dingenen J, Hanzalova K, Salem MA, Abel C, Seibert T, Giavalisco P, Wahl V (2019) Limited nitrogen availability has cultivardependent effects on potato tuber yield and tuber quality traits. Food Chem 288:170-177. https://doi.org/10.1016/j.foodchem. 2019.02 .113

Vos J (2009) Nitrogen responses and nitrogen management in potato. Potato Res 52:305-317. https://doi.org/10.1007/s11540-009-9145-2

Vrignon-Brenas S, Gay F, Ricard S, Snoeck D, Perron T, Mareschal L, Laclau JP, Gohet É, Malagoli P (2019) Nutrient management of immature rubber plantations. A review. Agron Sustain Dev 39:11. https://doi.org/10.1007/s13593-019-0554-6

Wang WN, Lu JW, Ren T, Li XK, Su W, Lu MX (2012) Evaluating regional mean optimal nitrogen rates in combination with indigenous nitrogen supply for rice production. Field Crop Res 137:37-48. https://doi.org/10.1016/j.fcr.2012.08.010

Yang KJ, Wang FX, Shock CC, Kang SZ, Huo ZL, Song N, Ma D (2017) Potato performance as influenced by the proportion of wetted soil volume and nitrogen under drip irrigation with plastic mulch. Agric Water Manage 179:260-270. https://doi.org/10.1016/j.agwat.2016.04.014

Ying H, Ye YL, Cui ZL, Chen XP (2017) Managing nitrogen for sustainable wheat production. J Clean Prod 162:1308-1316. https://doi. org/10.1016/j.jclepro.2017.05.196

Zhang YT, Wang HY, Lei QL, Luo JF, Lindsey S, Zhang JZ, Zhai LM, Wu SX, Zhang JS, Liu XX, Ren TZ, Liu HB (2018) Optimizing the nitrogen application rate for maize and wheat based on yield and environment on the Northern China Plain. Sci Total Environ 618: 1173-1183. https://doi.org/10.1016/j.scitotenv.2017.09.183

Zhao RR, He P, Xie JG, Johnston AM, Xu XP, Qiu SJ, Zhao SC (2016) Ecological intensification management of maize in Northeast China: agronomic and environmental response. Agric Ecosyst Environ 224: 123-130. https://doi.org/10.1016/j.agee.2016.03.038

References of the meta-analysis

Cai FS, Wang SF (2011) Effect of different nitrogen, phosphorus and potassium ratio on potato yield. Agric Technol Serv 28:14331434. https://doi.org/10.3969/j.issn.1004-8421.2011.10.031

Cai GM, Yuan E (2013) Experiment of formula fertilization by soil testing on potato using '3414' experiment design. Agric Technol Serv 30:244-246 CNKI:SUN:NJFW.0.2013-03-038

Cao Z, He WT, Hou XQ, Dang KK, Zhao XX, Yu XH (2017) Effects of nitrogen fertilizer application on nutrient absorption and yield of potato. Southwest China J Agric Sci 30:1600-1605. https://doi. org/10.16213/j.cnki.scjas.2017.7.023

Chen Y (2007) Preliminary study on the effect of balanced fertilization on winter potato. Fujian Agric Sci Technol 05:77-78. https://doi.org/ 10.3969/j.issn.0253-2301.2007.05.044
Chen YX (2008) The effect of N.P.K fertilizer application on the yield and benefit of potato. Chin Potato J 4:213-215. https://doi.org/10. 3969/j.issn.1672-3635.2008.04.006

Chen LJ (2010) '3414' fertilizer experiment of potato. Subtrop Agric Res 03:30-33 CNKI:SUN:GZZZ.0.2010-03-006

Chen FL (2011a) The study on effect of nitrogen, phosphorus and potassium fertilizer on potato yield. Agric Sci-Technol Inf 05:36-37. https://doi.org/10.15979/j.cnki.cn62-1057/s.2011.05.026

Chen SZ (2011b) Comparative experiment of different fertilizer rates for winter potato. Fujian Agric Sci Technol 01:81-82 CNKI:SUN: FJNK.0.2011-01-046

Chen BC (2014a) Effects of NPK ration on yield and quality of potato varieties. Dissertation, Northeast Agricultural University

Chen J (2014b) Study on formula fertilization by soil testing of maize and potato intercropping in Zhaoyang District of Zhaotong City. Mod Agric Sci Technol 42:44-44. https://doi.org/10.3969/j.issn.10075739.2014.23.018

Chen JG (2015) Effect of fertilization on nutrient uptake, yield and quality of potato under dry farming. Dissertation, Ningxia Agricultural University

Chen FY, Dai SR (2009) Discussion on the effect of N.P.K fertilizer application on the yield of crops. Fujian Sci Technol Trop Crops 4:11-14 CNKI:SUN:FJRK.0.2009-04-006

Chen WQ, Chen XS, Chen SC, Wu JM, Liu SK, Lu GQ (2010) Study on the effect of nitrogen, phosphorus and potassium fertilizer on potato. Shanghai Agric Sci Technol 06:9-12. https://doi.org/10.3969/j.issn. 1001-0106.2010.03.075

Chen RY, Meng ML, Liang HQ, Zhang J, Wang YH, Wang ZX (2012) Effects of different treatments of irrigation and fertilization on the yield and nitrogen utilization characteristic of potato. Chin Agr Sci Bull 38: 196-201. https://doi.org/10.3969/j.issn.1000-6850.2012.03.036

Dai SR (2010) NPK reasonable application rate on potato by establish fertilizer effect model of second degree polynomial using ' 3414 ' experimental design. Chin Agric Sci Bull 26:154-159 CNKI: SUN:ZNTB.0.2010-12-035

Dai LJ, Wu J, Liu MH, Ren MG, Liao WG (2010) Effect of N, P and K ratio on potato yeld of Kexuan no. 10. Mod Agric Sci Technol 13: 105-107 CNKI:SUN:ANHE.0.2010-13-064

Deng XQ, Fan GG, Li TS (2010) Analysis of different fertilizer proportions in potato. Tillage Cultivation 2:30-31 CNKI:SUN: GZZP.0.2010-02-017

Ding HB, Lei ZG, Deng KP, Yang FX, Liu WG (2008) Effect of different fertilization level on the agronomic traits and yield of potato. J Anhui Agric Sci 36:12338-12339 CNKI:SUN:AHNY.0.2008-28-114

Ding L, Hu QW, Yu SH (2012) Study on effect of formula fertilization by soil testing on vegetable virus-free potato. Hortic Seed 11:15-20. https://doi.org/10.3969/j.issn.2095-0896.2012.11.007

Dong Q, Zheng SL, Li GP, Yuan JC (2010) Effect of nitrogen level and top dressing proportion on quality of winter potato. Southwest China J Agric Sci 5:1571-1574 CNKI:SUN:XNYX.0.2010-05-040

Du WL (2013) Study on formula fertilization by soil testing on '3414' fertilizer field experiment of potato. Yunan Agric 10:32-34. https:// doi.org/10.3969/j.issn.1005-1627.2013.10.020

Duan Y, Zhang J, Li HC, Zhao PY, Sui DB, Yao JQ, An H, Jia YY (2014) Fertilization effect and nutrition use efficiency of potato in Inner Mongolia. Soil 46:212-217. https://doi.org/10.13758/j.cnki.tr. 2014.02.003

Fan HW (2011) The optimal ratio and rate of NPK fertilizer application in Minle country potato production. Chin Potato J 2:105-107 CNKI: SUN:MLSZ.0.2011-02-015

Fan H, Lin L, Wang SF (2013) Effects of different of NPK on potato production. Ningxia J Agric For Sci Technol 54:39-41 CNKI:SUN: NXNL.0.2013-04-019

Fang XD (2012) Experiment on '3414' fertilizer efficiency to potato in waterloggogenic soil in Zhao'an. Fujian Agric Sci Technol 5:62-63 CNKI:SUN:FJNK.0.2012-05-027 
Feng SQ (2014) Primary study on application amount of N fertilizer of winter potato. J Guangxi Agric 29:16-18. https://doi.org/10.3969/j. issn.1003-4374.2014.04.006

Feng Y, Sang YS, Chen T, Tang YC, Luo SH, Zhao L, Huang M, Li Q, Peng H (2013) Study of '3414' fertilizer efficiency test of purple potato. J Anhui Agric Sci 41:4338-4339. https://doi.org/10.3969/j. issn.0517-6611.2013.10.039

Gao XH (2008) Effect of nitrogen, phosphorus and potassium balanced fertilization on potato in coastal sandy soil. Chin Potato J 22:34-35. https://doi.org/10.3969/j.issn.1672-3635.2008.01.009

Gao XJ, Ren XR, Gao ZS, Zhang DH (2018) Nitrogen fertilizer gradient experiment of recommended fertilization method for potato. Yunnan Agric Sci Technol 303:15-17 CNKI:SUN:YNKJ.0.201805-005

Guo XZ, Liu YZ (2010) Effects of fertilizer application rate on potato using '3414' experimental design in Huzhu country. Mod Agric Sci Technol 2:123-123. https://doi.org/10.3969/j.issn.1007-5739.2010.02.080

Hao XS, Wu YH, Liu Y, Li HH, Ge HX, Chen J, Li XA, Yang XL (2016) Effects of combined application of nitrogen, phosphorus and potassium on the yield of winter potato in southern Shaanxi. Shaanxi J Agric Sci 62:25-27 CNKI:SUN:SNKX.0.2016-03-007

Hong CZ, Dai SR (2010) Soil-testing and formula fertilization index for potato in Nan'an city. Acta Agric Jiangxi 22:79-83 CNKI:SUN: JXNY.0.2010-09-022

Hu WJ, Jin Z, Liang H, Xue XX, Gao XM, Wang JG (2019) Effects of different fertilization methods on the yield and fertilizer ratio of potato. Inner Mongolia Agr Sci Technol 47:63-67. https://doi.org/ 10.3969/j.issn.2096-1197.2019.01.11

Huang CB, Zhong ZZ, Xie LH (2012) Preliminary report on the fertilizer efficiency experiment '3414' of potato in Xianpu County, Fujian Province. Subtrop Agric Res 8:13-16. https://doi.org/10.3969/j. issn.1673-0925.2012.01.004

Huang YL, Zhang CF, Zhang DW, Dong F (2018) Utilization rate of nitrogen, phosphorus and potassium in potato: a preliminary report. Chin Agr Sci Bull 34:39-44

Jiao F, Wu JH, Yu LH, Zhai RC (2013b) ${ }^{15} \mathrm{~N}$ tracer technique analysis of the absorption and utilisation of nitrogen fertiliser by potatoes. Nutr Cycl Agroecosyst 95:345-351. https://doi.org/10.1007/s10705013-9567-8

Jin FR, Pan WX, Meng DK, Zhu RB (2013) Experimental research on fertilizer for potato. Chin Hortic Abstr 29:44-45. https://doi.org/10. 3969/j.issn.1672-0873.2013.09.016

Kong LY, Peng QS, Xiong Y, Zhou FC (2004) Effect of balanced fertilization on the yield and quality of potato. Soil Fertil 3:17-19 CNKI: SUN:TRFL.0.2004-03-005

Li JH (2006) Characteristics of nitrogen utilization under different nitrogen strategies and nitrogen diagnosis in potato. Dissertation, Jilin Agricultural University

Li JJ (2009) Potato's '3414' fertilizer effect experiment. J Guangxi Agric 5:19-21. https://doi.org/10.3969/j.issn.1003-4374.2009.05.006

Li ZP (2011) Effect of nitrogen, phosphorus and potassium fertilizer combined application on winter potato. Fujian Agric Sci Technol 4:70-71. https://doi.org/10.3969/j.issn.0253-2301.2011.04.040

Li CL, Dai YR (2011) Analysis of potato yield function with different proportion of nitrogen, phosphorus and potassium fertilizer. Anhui Agric Sci Bull 10:82-83 Doi: CNKI:SUN:XDNX.0.2011-10-041

Li ZM, Wei YH (2019) Preliminary report on the total control of $2+\mathrm{X}_{1}$ nitrogen fertilizer for potato in Alpine and humid cold areas. Agric Technol 39:45-47. https://doi.org/10.19754/j.nyyjs.20190430021

Li HX, Xin XH, Zhang SY, Liu ZJ, Chen XT, Du XX (2009) Effects of nitrogen rate on potato yield and benefit. Gansu Agric Sci Technol 2:31-32 doi: CNKI:SUN:GSNK.0.2009-02-012

Li TW, Zhang XS, Mou CJ (2010a) A comparative experiment on formula fertilization according to soil testing in potato. Mod Sgric Sci Technol 15:141-145 doi: CNKI:SUN:ANHE.0.2010-15-090
Li XP, Chen SZ, Wang HZ, Weng DH (2010b) Suitable application rate of nitrogen and potassium fertilizer in potato. Fujian Sci Technol Rice Wheat 3:21-23 Doi: CNKI:SUN:FJDM.0.2010-03-007

Li XH, Cao WY, Zhou YL, Liu Q, Xu YJ, Wang D, Fang Y, Liu YX (2011) Study on potato '3414' fertilizer field experiment in Chenggu country. Mod Agric Sci Technol 3:121-131 doi: CNKI:SUN: ANHE.0.2011-03-070

Li XB, An K, Fang ZW, He Q, Zhang XL (2013) Preliminary report on formula fertilization according to soil testing in winter potato in Guangdong. Chin J Trop Agric 33:4-6. https://doi.org/10.3969/j. issn.1009-2196.2013.12.002

Liang NZ (2013a) Effects of different dosages of $\mathrm{N}$ fertilization and fertilization pattern on yield of winter potato. Chin Hortic Abstr 7: 26-28 Doi: CNKI:SUN:YUWZ.0.2013-07-013

Liang ZR (2013b) Effect of NPK fertilizer on potato in Alpine area. Agric Technol Serv 30:136-137. https://doi.org/10.3969/j.issn.10048421.2013.02.027

Liao JL (2009) Effect of water and fertilizers managing on potato growth and WUE and soil fertility in dry land. Dissertation, Northwest A \& F University

Liao GZ (2014) Preliminary report on NPK fertilizer optimization for potato. Agric Technol Serv 31:80-81. https://doi.org/10.3969/j. issn.1004-8421.2014.05.057

Liao SX, Wang XQ (2009) Effect of formula fertilization on yield of virus-free potato. Agric Technol Sci 26:43-44. https://doi.org/10. 3969/j.issn.1004-8421.2009.06.032

Lin YZ, Li XP, Jiang ZW, Weng DH (2012) Nitrogen absorption and accumulation and fertilization of potatoes. Fujian J Agric Sci 27: 679-684 Doi: CNKI:SUN:FJNX.0.2012-07-006

Liu WX, Duan SP, Hu H, Zhai JP (2007) Effect of nitrogen, phosphorus and potassium coordination employment on yield of first order nonpoisonous potato protospecies and quality of seed tuber. J Anhui Agric Sci 35:6866-6867 Doi: CNKI:SUN:AHNY.0.2007-22-087

Liu HS, Yang XD, Zhang XH, Fu GZ (2010b) Optimization of fertilization for potato production in semi-arid areas. Chin Potato J 6:357359 Doi: CNKI:SUN:MLSZ.0.2010-06-012

Liu XE, Liu X, Peng DZ (2011a) Test of fertilizer '3414' on the potato plant. Shaanxi Agric Sci 2:29-31 Doi: CNKI:SUN:SNKX.0.201102-013

Liu YF, Chen YQ, Li YP (2011b) Analysis of fertilization on potato using '3414' experiment design in different soil types. Tillage Cultivation 5:29-30. https://doi.org/10.3969/j.issn.1008-2239.2011.05.015

Liu WJ, Liu YZ, Zhou CP (2012) Study on effect of nitrogen, phosphorus and potassium fertilizer on virus-free potato. Tillage Cultivation 1: 11-14. https://doi.org/10.3969/j.issn.1008-2239.2012.01.005

Liu FC, Ao WQ, Wang AH (2013a) Effect of different NPK fertilizer ratio on potato yield. Agric Technol Serv 30:1066-1069. https://doi. org/10.3969/j.issn.1004-8421.2013.10.018

Liu WZ, Yu WQ, Hu GM, Zhao XF, Li P, Huai BD, Tian YH, Sui WZ (2013b) Effect of formula fertilization by soil testing on yield of potato in north cold region. Chin Potato J 6:353-357. https://doi. org/10.3969/j.issn.1672-3635.2013.06.009

Liu ZL, Jiao J, Zhang YY, Gu DY, Gao JJ, Liu SQ (2018) Effect of nitrogen, phosphorus and potassium fertilizers on potato in double cropping cultivated region. J Northeast Agric Sci 43:35-39. https:// doi.org/10.16423/j.cnki.1003-8701.2018.02.008

Long RP, Liu YJ, Che JX, Guo HC (2011a) Study on '3414' fertilizer field experiment of potato in Jianchuan country. Yunnan Province, Potato Industry and Technology Poverty Alleviation

Long XD, Yang X, Long JC, Yang JL (2011b) Study on '3414' fertilizer field experiment of potato in sandy loam soil in Pingluo town, Jinping County. Mod Sgric Sci Technol 19:150-151 doi: CNKI: SUN:ANHE.0.2011-19-091

Lu P (2017) Analysis of fertilizer '3414' on the potato. Agric Technol Serv 34:20-21. https://doi.org/10.3969/j.issn.1004-8421.2017.11. 011 
Lu JH, Wang BL, Wang SY, Wang JQ, Yang SH (2011) '3414+1' fertilizer efficiency experiment for potato. J Hebei Agric Sci 15:48-50 Doi: CNKI:SUN:HBKO.0.2011-03-017

Luan HG, Xie HS, Wang GZ, Zi ZL, Bo QZ, Ji ST (2014) Experiment on reasonable amount of nitrogen, phosphorus and potassium in spring potato in Luliang County. Yunan Agric Sci Technol 6:4-7 doi: CNKI:SUN:YNKJ.0.2014-06-001

Luo LJ, Wu GF, Zhong XL, Wang P (2011) Effect of fertilizer '3414' on the potato. Agric Technol Serv 28:475-476 Doi: CNKI:SUN: NJFW.0.2011-04-049

Ma ZQ (2014) Effect of balanced fertilization on potato yield of Qingshu 10 cultivar. Agric Dev Equip 7:71-71. https://doi.org/10.3969/j. issn.1673-9205.2014.07.055

Ma RB, Ma JL, Su JG, Han XB, Wang X, Wang CY (2008) Effect of NPK fertilizer on potato in Majian township, Xiji County. Ningxia J Agric For Sci Technol 6:74-75 doi: CNKI:SUN:NXNL.0.2008-06-045

Ma WJ, Tong YA, Gao PC (2012) Effect of balanced fertilization on the yield and quality of potato. Hortic Seed 10:48-52. https://doi.org/10. 3969/j.issn.2095-0896.2012.10.018

Meng Y, He WT, Hou XQ, Cao Z (2019) Effect of fertilization on dry matter accumulation and fertilizer efficiency of potato in rained region. Mol Plant Breed 17:4144-4152 Doi: CNKI:SUN: FZZW.0.2019-12-043

Peng H (2015) Effects of '3414' fertilization experiment on economic character and yield of potato. J Anhui Agric Sci 43:73-74. https:// doi.org/10.13989/j.cnki.0517-6611.2015.09.031

Peng X, Liu LH, Cai J (2011) Preliminary study on formula fertilization by soil testing on potato. Mod Agric Sci Technol 15:115-116 doi: CNKI:SUN:ANHE.0.2011-15-065

Qian CX, Kong LY, Chen JL, Xu FH, Chen JK, Xu CX, Lu DH, Feng JW (2013) A field experiment of fertilization based on soil diagnosis in a '3414' design. Chin Potato J 27:306-310. https://doi.org/10. 3969/j.issn.1672-3635.2013.05.012

Qu CX, Wang Q, Zhang CH, Liu Y (2013) Preliminary report on '3414' fertilizer field experiment of potato in southern Shaanxi. Shaanxi J Agric Sci 1:50-51. https://doi.org/10.3969/j.issn.0488-5368.2013. 01.017

Ren WJ, Ren L, Liu SX (2015) The research on balanced fertilization of potato plastic film mulching cultivation in the semi-arid region. Chin J Soil Sci 46:157-161. https://doi.org/10.19336/j.cnki.trtb.2015.01.027

Ren XR, Wang C, Yan H, Li ZW, Ni M, Chen XW, Chen ZB (2017) Effects of different fertilizer application on yield of potato no.9. J Kunming Univ 39:82-84 Doi: CNKI:SUN:KMSG.0.2017-06-019

Shao K (2018) Experimental study on formula fertilization by soil testing effect and fertilizer utilization ratio of potato. Mod Agric Sci Technol 8:7-9. https://doi.org/10.15979/j.cnki.cn62-2015/s.2018.08.002

Shi M, Zhou YF, Li SL, Tang Y (2012) Effects of '3414' fertilization experiment on economic character and yield of potato. Agric Technol Serv 6:711-712. https://doi.org/10.3969/j.issn.1004-8421. 2012.06.032

Shu HB (2016) The effect of N K rate on growth, yield and quality of potato in yellow-cinnamon soil district. Dissertation, Huazhong Agricultural University

Song ML (2015) Nitrogen to nitrogen utilization and purple potatoes the influence of yield and quality. Dissertation, Sichuan Agricultural University

Sun CC (2014) Study on '3414' experiment applying nitrogen, phosphorus and potassium to potato. Fujian Agric Sci Technol 45:13-15. https://doi.org/10.3969/j.issn.0253-2301.2014.07.005

Tan ZH (2012) Study on the regression experiment of nitrogen, phosphorus and potassium fertilizer on potato. Anhui Agric Sci Bull 6:81-83 Doi: CNKI:SUN:XDNX.0.2012-06-040

Tan QK, Li HS, Lin J, Zheng PL, Zheng RF, Zheng WP, Chen JZ (2012) Effect of different fertilization level on the agronomic traits and yield of potato. Chin Agric Sci Bull 28:166-171. https://doi.org/10.3969/ j.issn.1000-6850.2012.33.033
Tang JL, Xu Z, Ding XM, Li M, Ding HR, Sun YJ, Wu GZ, Liu X (2017) Effects of $N$ fertilization on yield and quality of potato. Biol Disaster Sci 40:205-208 Doi: CNKI:SUN:HXZI.0.2017-03-015

Tian SC, Ma JJ (2011) Study on the potato optimum application model test in Pingluo country of Ningxia. J Yulin Univ 4:1-4. https://doi. org/10.3969/j.issn.1008-3871.2011.04.002

Tian YJ, Xu NS, Sang YQ, Li XP (2014) Fertilizer requirement of potato variety Gama 2 in Yunnan Province. Chin Potato J 5:295-300. https://doi.org/10.3969/j.issn.1672-3635.2014.05.009

Wang B (2014) Effect of different nitrogen, phosphorus and potassium fertilizer ratio on potato yield. Agric Technol Serv 31:83-85. https:// doi.org/10.3969/j.issn.1004-8421.2014.05.059

Wang DJ (2016a) Different nitrogen levels on potato growth, yield and verticillium wilt incidence. Dissertation, Northeast Agricultural University

Wang T (2016b) Effect of fertilization on nutrient uptake characteristics, yield and quality of potato in Ningxia rainfed area. Dissertation, Ningxia Agricultural University

Wang FW (2017) Study on '3414' fertilizer field experiment of winter potato. Friends Farmers Rich 2:126-126. https://doi.org/10.3969/j. issn.1003-1650.2017.02.120

Wang FQ, Cai LY (2016) Study on the total nitrogen fertilizer application rate control of ' $2+X$ ' experiment for potato in Chishui City, Guizhou Province. Agric Technol Serv 33:90-91 Doi: CNKI:SUN: NJFW.0.2016-01-060

Wang H, Qu XT, Xu XB, Li Y (2014a) Regression relationship between nitrogen application rate and yield in potato using ' 3414 ' densification experimental design. Mod Agric Sci Technol 4:76-76,81. https://doi.org/10.3969/j.issn.1007-5739.2014.04.048

Wang R, Wang JJ, Ding GY, Gao LP, Zhang CY (2014b) Effects of nitrogen fertilizer on potato yield using ' 3414 ' experimental design. Mod Agric Sci Technol 1:110-110. https://doi.org/10.3969/j.issn. 1007-5739.2014.01.068

Wang ZQ, Jiang LL, Gong ZP (2014c) Effect of nitrogen levels on yield of fried potato and establishment of nitrogen status diagnose index. $J$ Northeast Agric Univ 7:19-25. https://doi.org/10.19720/j.cnki.issn. 1005-9369.2014.07.004

Wei DP, Song SH, Wei JF, Liang H, Pan ZY, Chen C (2015a) Effects of nitrogen application rate on physiological characteristics and yield of winter potato. Jiangsu Agric Sci 43:122-124. https://doi.org/10. 15889/j.issn.1002-1302.2015.11.036

Wei JF, Wei QY, Liang ZH, Song SH, Wei DP, Liang H (2015b) Effects of nitrogen application rates of growth, yield and quality of winter potato. J Henan Agric Sci 44:61-64. Doi: CNKI:SUN: HNNY.0.2015-12-016

Wen BS (2009) Balanced fertilization experiment of potato. Fujian J Agric Sci 01:53-54 Doi: CNKI:SUN:FJNK.0.2009-01-043

Wen GC (2018) Analysis of nitrogen application rate on potato. Agric Eng Technol 38:23-23. https://doi.org/10.16815/j.cnki.11-5436/s. 2018.11.015

Wen YN, Gu CP, Wang K (2008) Effects of different N, P and K application amount on yield of potato. Guizhou Agric Sci 36:116-117. https://doi.org/10.3969/j.issn.1001-3601.2008.01.039

Wen GC, Huang SL, Deng LY (2013) '3414' fertilizer experiment of potato 8:103-103. doi: https://doi.org/10.3969/j.issn.1003-1650. 2013.08.085

Wu X (2010) Preliminary report on different nitrogen application rates of potato. Agric Sci-Technol Inf 13:36-37. https://doi.org/10.15979/j. cnki.cn62-1057/s.2010.13.009

Wu ZX (2011) Effect of different N, P and K fertilizer proportion on potato. Agric Technol Serv 28:58-61 Doi: CNKI:SUN: NJFW.0.2011-01-038

Wu BQ (2012) Study on '3414+1' fertilizer field experiment of potato of Weiyu no. 3 in Daozhen country. Agric Technol Serv 29:562-563. https://doi.org/10.3969/j.issn.1004-8421.2012.05.030 
Wu YB (2015) Effect of NPK fertilizers application on production characteristics of carrot, potato and celery in Xining outskirts. Dissertation, Lanzhou University

Wu YB, Zhang LG, Qiu YH, Shi CD (2012) Study on index systems of formula fertilization with soil testing for potato on the hilly loess plateau of eastern Gansu Province. Acta Agric Boreali-occidentalis Sin 21:191-196. https://doi.org/10.7606/j.issn.1004-1389.2012.10. 035

Wu QY, Xia JH, Li QY, Zeng XH, He TJ (2015) Effects of different N-P$\mathrm{K}$ ratio and planting density on yield and starch content of potato in Central Guizhou. Guizhou Agric Sci 43:43-46. https://doi.org/10. 3969/j.issn.1001-3601.2015.02.013

Xiang J, Fu WJ, Zhu SQ (2016) A comparative experiment on '3414' fertilizer field experiment of Zhongshu 5. Bull Agric Sci Technol 6: 137-139

Xiao HJ, Sui RF, Gou JL, Zhou RR, Liu L (2011) Effects of different N, P and $\mathrm{K}$ proportion on yield and economic benefit of potato planted in areas with different elevation. Guizhou Agric Sci 39:58-60 Doi: CNKI:SUN:GATE.0.2011-09-016

Xiao Q, Meng ML, Chen YJ, Yang LH, Song SH, Ren SY (2014) Effects of fertilizer application on potato yield and water use efficiency dry areas at northern foot of Yinshan Mountain. Agric Res Arid Areas 32:112-118. https://doi.org/10.7606/j.issn.1000-7601.2014.06.019

Yang Y (2011) Effect of formula fertilization by soil testing on potato in Dejiang country. Agric Technol Serv 28:1435-1436. https://doi.org/ 10.3969/j.issn.1004-8421.2011.10.032

Yang DH (2012) Effects of different fertilizer rates and methods on yield, nutrient accumulation and quality of potato in Xiangyang city. Dissertation, Huazhong Agricultural University

Yang QL (2013) Report on formula fertilization by soil testing on potato using '3414' experimental design in Qianan country. Gansu Agric 15:60-61. https://doi.org/10.15979/j.cn62-1104/f.2013.15.047

Yang SH (2014) Study on the total nitrogen fertilizer application rate control of ' $2+X$ ' experiment for potato. Agric Technol Serv 31: 86-86. https://doi.org/10.3969/j.issn.1004-8421.2014.03.066

Yang WC (2015) Study on formula fertilization by soil testing on '3414' fertilizer field experiment of potato. Friends Farmers Rich 10:22 143 Doi: CNKI:SUN:NMZF.0.2015-10-128

Yang B, Li L (2010) Fertilizer effect model for Weiyu 3, the main potato variety in Hezhang country. Guizhou Agric Sci 38:135-138. https:// doi.org/10.3969/j.issn.1001-3601.2010.08.046

Yang H, Tan KJ (2011) Study on potato fertilization effect of different fertility levels in Liping County. Tillage Cultivation 5:31-32 Doi: CNKI:SUN:GZZP.0.2011-05-016

Yang B, Yang YQ, Lu D, Hu J (2004) Study on balanced fertilization of virus-free potatoes in Bijie area. Tillage Cultivation 1:23-25 Doi: CNKI:SUN:GZZP.0.2004-01-008

Yang GH, Zhang QC, Wu SF (2008) Effects of different NPK application rates on potato yield. Tillage Cultivation 42:59-59. https://doi.org/ 10.3969/j.issn.1008-2239.2008.01.017

Yang LH, Meng ML, Chen YJ, Xiao Q, Song SH, Chen F (2013) Effects of fertilizers application on yield and quality of potato. Chin Agric Sci Bull 29:136-140. https://doi.org/10.3969/j.issn.1000-6850. 2013.12 .023

Yao BQ (2008) NPK fertilizer response and optimum application rate for winter potatoes. Fujian J Agric Sci 23:191-195. https://doi.org/10. 3969/j.issn.1008-0384.2008.02.016

Yin DK, Xu HH, Ding LX, Liu ZQ, Feng TM (2012) The study on mathematics model establishment NPK formula fertilization and experimental of optimum amount of fertilization in Atlantic potato variety. J Agric Univ (natural science) 29:11-14 Doi: CNKI:SUN: LYXI.0.2012-01-005

Yu XB (2016) Effects of fertilization on soil properties and potato yield. Dissertation, Inner Mongolia Agricultural University

Yue C, Xiao SJ, Wang HY, Wang Y, Liu LY, Teng S, Luo P, Liu YR, Lou P, Mao YC, Li YS (2019) Effect of nitrogen fertilizer rate on yield and nitrogen use efficiency of different winter potato varieties. Soil Fertil Sci China 2:119-125 Doi: CNKI:SUN:TRFL.0.2019-02018

Zeng GL (2008) Determination of optimum nitrogen rate for potato in Huzhu country. Shaanxi Agric Sci 2:15-17 Doi: CNKI:SUN: SNKX.0.2008-02-008

Zhang XL (2010) Studies on fertilizer requirement pattern and fertilizer efficiency of potato in winter-fallow fields. Dissertation, Hunan Agricultural University

Zhang J (2012) Effects of different amounts and ratios of N, P, K on the yield, quality, and nitrogen absorption utilization characteristics of potato. Dissertation, Inner Mongolia Agricultural University

Zhang XY (2013) Effects of different nitrogen rate on potato yield. Agric Sci-Technol Inf 7:41-42. https://doi.org/10.15979/j.cnki.cn621057/s.2013.07.022

Zhang Y, Li HX (2011) Effect of nitrogen, phosphorus and potassium fertilizer on potato yield. Ningxia J Agric For Sci Technol 52:15-17. https://doi.org/10.3969/j.issn.1002-204X.2011.12.007

Zhang XY, Li YF, Li XF, Fan B (2005) Effects on growing and yield of potatoes by different quantity of fertilizer application. Acta Agr Boreali-Sinica 20:142-143. https://doi.org/10.7668/hbnxb.2005. S1.037

Zhang X, Shi JZ, Shi QL (2009) Effect of '3414' fertilizer efficiency experiment for potato. Agric Technol Serv 26:61-63. https://doi. org/10.3969/j.issn.1004-8421.2009.01.046

Zhang W, Yang DH, Huang XQ, Jiang LH, Lin YM, Lu MX, Zhao ZQ (2016) Effect of nitrogen rate on the yield, quality and economic benefit of potato in Xiangyang city. Soil Fertil Sci China 1:72-76. https://doi.org/10.11838/sfsc.20160112

Zhang JQ, Li M, Wang Q, Ding TQ, Hu ZM (2019) Effects of nitrogen phosphorus and potassium combination on the yield of potato in Golmud area. Hubei Agric Sci 12:42-44. https://doi.org/10.14088/ j.cnki.issn0439-8114.2019.12.011

Zheng XJ (2017) Preliminary study on effect of nitrogen, phosphorus and potassium fertilizer on potato. Agric Technol Serv 34:69-70. https:// doi.org/10.3969/j.issn.1004-8421.2017.13.052

Zheng HL, Liu YC, Qin YL, Chen Y, Fan MS (2015) Establishing dynamic thresholds for potato nitrogen status diagnosis with the SPAD chlorophyll meter. J Integr Agric 14:190-195. https://doi.org/10. 1016/S2095-3119(14)60925-4

Zhong YF (2011) Studies om fertilizer efficiency of N-P-K compound fertilizer '3414' and its appropriate dose in potato field. Fujian agricultural. Sci Technol 5:96-97 doi: CNKI:SUN:FJNK.0.2011-05050

Zhou ZY, Zhang XM, Wang P, Sun HR, Jiang TQ, He JP (2013) Effects of different levels of nitrogen on nitrogen uptake, yield and quality of potato. J Anhui Agr Sci 41:6671-6673. https://doi.org/10.13989/ j.cnki.0517-6611.2013.15.127

Zhou L, Long GQ, Tang L, Zheng Y (2017) Analysis on N application rates considering yield and $\mathrm{N}_{2} \mathrm{O}$ emission in potato production. Trans Chin Soc Agric Eng 33:155-166. https://doi.org/10.11975/j. issn.1002-6819.2017.02.021

Zhu M (2016) Effect of nitrogen, phosphorus and potassium fertilizer on potato growth. Anhui Agric Sci Bull 20:22-23. https://doi.org/10. 16377/j.cnki.issn1007-7731.2016.20.011

Zhuo XS (2010) Research on effects of N, P and K fertilizer on potato in coastal sandy soil based on '3414' test model. Acta Agric Jiangxi 22:84-86 Doi: CNKI:SUN:JXNY.0.2010-07-030

Zou XH, Tong JM (2012) Study on fertilizer effect on winter potato. Agric Technol 12:75-76 Doi: CNKI:SUN:NYYS.0.2012-12-057

Publisher's note Springer Nature remains neutral with regard to jurisdictional claims in published maps and institutional affiliations. 